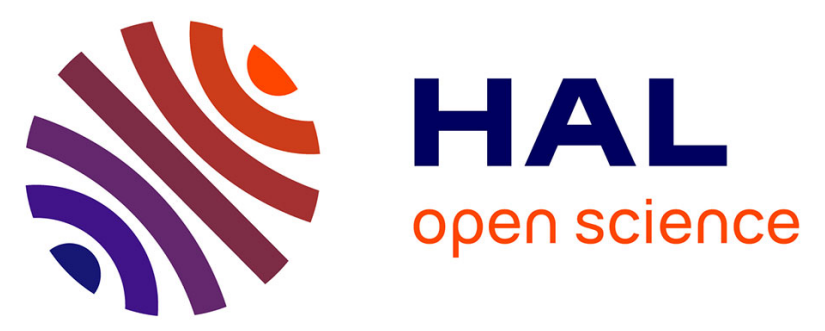

\title{
Influence of environmental parameters on the distribution of bacterial lipids in soils from the French Alps: Implications for paleo-reconstructions
}

Pierre Véquaud, Sylvie Derenne, Christelle Anquetil, Sylvie Collin, Jérôme Poulenard, Pierre Sabatier, Arnaud Huguet

\section{To cite this version:}

Pierre Véquaud, Sylvie Derenne, Christelle Anquetil, Sylvie Collin, Jérôme Poulenard, et al.. Influence of environmental parameters on the distribution of bacterial lipids in soils from the French Alps: Implications for paleo-reconstructions. Organic Geochemistry, 2021, pp.104194. 10.1016/j.orggeochem.2021.104194 . hal-03157067

\section{HAL Id: hal-03157067 \\ https://hal.science/hal-03157067}

Submitted on 4 Oct 2021

HAL is a multi-disciplinary open access archive for the deposit and dissemination of scientific research documents, whether they are published or not. The documents may come from teaching and research institutions in France or abroad, or from public or private research centers.
L'archive ouverte pluridisciplinaire HAL, est destinée au dépôt et à la diffusion de documents scientifiques de niveau recherche, publiés ou non, émanant des établissements d'enseignement et de recherche français ou étrangers, des laboratoires publics ou privés. 
Influence of environmental parameters on the distribution of bacterial lipids in soils from the French Alps: Implications for paleo-reconstructions

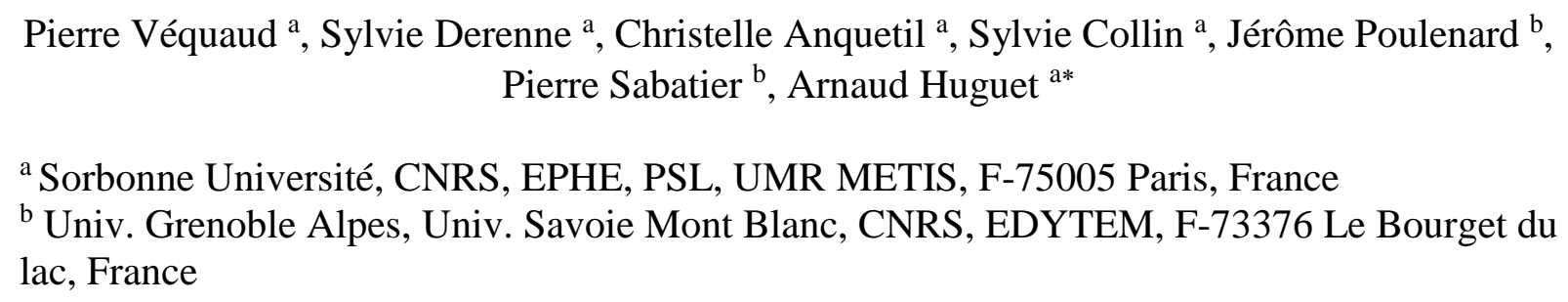

\section{Abstract}

Branched glycerol dialkyl glycerol tetraethers (brGDGTs) are a family of bacterial lipids widely used for temperature and $\mathrm{pH}$ reconstructions in terrestrial settings. 3-hydroxy fatty acids (3-OH FAs) with 10 to 18 carbon atoms, produced by Gram-negative bacteria, have been recently proposed as independent and complementary proxies of temperature and $\mathrm{pH}$ in terrestrial environments. Nevertheless, the correlations between mean annual air temperature (MAAT)/pH and bacterial lipid (brGDGTs/3-OH FAs) distribution show a large degree of scatter, as the relative abundance of these lipids is influenced by factors other than temperature and $\mathrm{pH}$. A full understanding of the environmental parameters influencing bacterial lipid distribution in soils is required to increase the reliability of the temperature and $\mathrm{pH}$ proxies based on these compounds in terrestrial environments. The aim of this work was to determine and quantify the cumulative effect of environmental parameters on the distribution of both brGDGTs and 3-OH FAs along a well-documented composite altitudinal transect in the French Alps (234-2,748 m). Redundancy analysis revealed that the influence of local parameters ( $\mathrm{pH}$ and to a lesser extent soil moisture and grain size, related to vegetation and soil types) on brGDGT and 3-OH FA distribution amounted to $48.1 \%$ and $26.1 \%$, respectively, and was predominant over MAAT. This likely explained the weak or lack of relationships between MAAT and brGDGT-/3-OH FA-based indices in this region. The identification of lipids whose fractional abundance is correlated with MAAT or $\mathrm{pH}$ allowed the development of local calibrations with MAAT/pH applicable in the French Alps which are representative of highly contrasted microenvironments, reflecting different types of soil and vegetation. The present study highlighted the importance of constraining the environmental factors affecting the

${ }^{*}$ Corresponding author. Tel: + 33-144-275-172; fax: +33-144-275-150.

E-mail address: arnaud.huguet@ sorbonne-universite.fr (A. Huguet). 
distribution of 3-OH FAs and brGDGTs in terrestrial settings prior to any paleoenvironmental reconstruction. Such an approach should be reproduced in other sites, where local factors could also strongly influence the bacterial lipid distribution.

Keywords: 3-hydroxy fatty acids; branched GDGTs; French Alps soils; altitudinal transect; environmental parameters; local calibration

\section{Introduction}

Direct measurement of environmental data, such as temperature and precipitation, has been possible for the last two centuries, the so-called "instrumental" period. Beyond this period, it is necessary to use indirect approaches to obtain information on the different environmental parameters. "Indirect" indicators of these parameters - so-called proxies - have thus been developed and used regularly for last decades.

Organic biomarkers have been of great interest to the scientific community for the reconstruction of past environments over the last decades (Eglinton and Eglinton, 2008), especially microbial compounds. Microorganisms modify the lipid composition of their membranes (e.g. carbon chain length, number of unsaturations, branching level) in response to variations of environmental parameters ( $\mathrm{pH}$, temperature, osmotic pressure) (Ernst et al., 2016). Such modifications are considered to maintain a functional fluidity and permeability of the microbial membrane (Singer and Nicolson, 1972; Sinensky, 1974; Hazel and Williams, 1990; Denich et al., 2003). These microbial lipids can be preserved in soils and sediments and be used as proxies of past environmental conditions.

In this context, glycerol dialkyl glycerol tetraethers (GDGTs) are a family of microbial lipids widely used for paleoenvironmental reconstructions These compounds are ubiquitous in terrestrial (Weijers et al., 2007; Peterse et al., 2012; De Jonge et al., 2014; Naafs et al., 2017) and aquatic environments (Schouten et al., 2002, 2012; Powers et al., 2010; Peterse et al., 2015; Weber et al., 2015). They are characterized by aliphatic chains connected to two glycerol units via ether bonds. Two groups of GDGTs - isoprenoid and branched - can be distinguished (Schouten et al., 2013 and references therein). Isoprenoid GDGTs (iGDGTs) are produced by archaea. In contrast, GDGTs with branched chains but no isoprenoid alkyl chains - so-called branched GDGTs (brGDGTs) - are produced by still unidentified bacteria, although some of them may belong to the phylum Acidobacteria (Sinninghe Damsté et al., 2011, 2014, 2018). They were discovered in peat (Sinninghe Damsté et al., 2000). The analysis of brGDGTs in a 
large number of soils distributed worldwide then showed that the relative distribution of these compounds is dependent on environmental parameters, mainly temperature and $\mathrm{pH}$ (Weijers et al., 2007; De Jonge et al., 2014, 2019).

Despite the wide application of brGDGT indices for paleoenvironmental reconstructions in terrestrial settings (Weijers et al., 2011; Wang et al., 2017; Coffinet et al., 2018), the derived results must be interpreted with caution, as parameters other than temperature or pH, such as humidity (Huguet et al., 2010; Menges et al., 2014), soil type (Davtian et al., 2016; Mueller-Niggemann et al., 2016), vegetation composition (Weijers et al., 2011; Naeher et al., 2014; Liang et al., 2019) or seasonality (Huguet et al., 2013) can also have an influence on the relative abundances of brGDGTs. These lipids are the only molecular proxies of temperature and $\mathrm{pH}$ available in the terrestrial environment to date, as most of the available proxies have been developed in oceanic environments. Despite improvements in brGDGT analytical methods and use of refined calibration models (De Jonge et al., 2014; Hopmans et al., 2016; Dearing Crampton-Flood et al., 2020), the Root Mean Square Error (RMSE) associated with Mean Annual Air Temperature (MAAT) reconstruction using the global brGDGT calibrations in soils remains high $\left(>4^{\circ} \mathrm{C}\right)$, possibly due to the lack of knowledge on all influencing environmental parameters. The development of new molecular proxies, independent of and complementary to brGDGTs, is essential to improve the reliability of environmental reconstructions in terrestrial settings.

Recent studies (Wang et al., 2016, 2018; Huguet et al., 2019; Yang et al., 2020) have unveiled the potential of another family of lipids -3-hydroxy fatty acids (3-OH FAs) - for temperature and $\mathrm{pH}$ reconstructions. 3-OH FAs with 10 to 18 carbon atoms are specifically produced by all Gram-negative bacteria and are bound to the lipopolysaccharide (LPS; main component of the outer membrane) by ester or amide bonds. 3-OH FAs are part of the lipid A, which anchors the LPS in the outer membrane of Gram-negative bacteria. Three types of 3-OH FAs can be distinguished: with normal (i.e. straight and unbranched) or branched carbon chains, either iso or anteiso. These compounds were widely used (i) to quantify Gram-negative bacteria in clinical studies and detect the presence of endotoxins they release (Wollenweber and Rietschel, 1990; Saraf et al., 1997; Szponar et al., 2002, 2003; Keinänen et al., 2003) and (ii) to characterize and quantify Gram-negative bacteria communities in environmental samples such as aerosols (Lee et al., 2004; Cheng et al., 2012), dissolved organic matter (Wakeham et al., 2003), or soils (Zelles et al., 1995; Zelles, 1999).

3-OH FAs have been recently proposed as proxies of temperature and $\mathrm{pH}$ in terrestrial environments after analysis of these compounds in 26 soils along Mount Shennongjia, China 
100 (Wang et al., 2016). New indices were developed, with $\mathrm{RAN}_{15}$ and $\mathrm{RAN}_{17}$ (defined as the ratio of $\mathrm{C}_{15}$ or $\mathrm{C}_{17}$ anteiso 3-OH FAs to normal $\mathrm{C}_{15}$ or $\mathrm{C}_{17} 3$-OH FAs) being correlated with MAAT and RIAN (defined as -log ([normal 3-OH FAs]/[anteiso+iso 3-OH FAs])) being dependent on soil $\mathrm{pH}$.

Significant relationships between 3-OH FA distribution and temperature as well as $\mathrm{pH}$ were similarly observed along two additional altitudinal transects: Mount Majella in Italy and Mount Rungwe in Tanzania (Huguet et al., 2019). The $\mathrm{RAN}_{15} / \mathrm{RAN}_{17}$ indices were negatively correlated to air temperature along the three mountains investigated so far (Wang et al., 2016; Huguet et al., 2019). This suggests that Gram-negative bacteria respond to colder temperatures with an increase in anteiso- $\mathrm{C}_{15} / \mathrm{C}_{17}$ vs. $n-\mathrm{C}_{15} / \mathrm{C}_{17} 3$-OH FAs in order to maintain a proper fluidity and optimal state of the bacterial membrane, the so-called homeoviscous adaptation mechanism (Sinensky, 1974; Hazel and Williams, 1990). Nevertheless, the relationships between RAN $_{15}$ and MAAT along Mts. Shennongjia, Rungwe and Majella showed the same slopes but different intercepts (Wang et al., 2016; Huguet et al., 2019), suggesting that regional calibrations may be more adapted to apply $\mathrm{RAN}_{15}$ as a temperature proxy in soils. In contrast, a significant $\left(\mathrm{R}^{2}=\right.$ 0.60) combined calibration between $\mathrm{RAN}_{17}$ and MAAT could be established using data from Mts. Shennongjia, Rungwe and Majella (Wang et al., 2016; Huguet et al., 2019). Similarly, RIAN was shown to be strongly negatively correlated with soil $\mathrm{pH}$ along the three aforementioned mountains (Wang et al., 2016; Huguet et al., 2019), reflecting a general relative increase in normal homologues compared to branched (iso and anteiso) ones with increasing $\mathrm{pH}$. This mechanism was suggested to reduce the permeability and fluidity of the membrane for the cell to cope with lower pH (Watanabe and Takakuwa, 1984; Lepage et al., 1987; Russell, 1989; Russell et al., 1995; Denich et al., 2003; Beales, 2004). 3-OH FA indices were recently applied to estimate temperature and hydrological changes over the last 10,000 years in a speleothem from China (Wang et al., 2018), showing the potential of 3-OH FAs as independent tools for environmental reconstruction in terrestrial settings. A very recent study based on marine sediments from the North Pacific Ocean suggested that the distribution of 3-OH FAs could also be used to reconstruct sea surface temperature (Yang et al., 2020).

Even though these results are promising, the linear regressions between $\mathrm{pH} / \mathrm{MAAT}$ data and 3-OH FA indices in terrestrial environments are still based on a rather small dataset (ca. 70 soil samples) and show a large degree of scatter, leading to substantial errors in 3-OH 131 FA-based MAAT and $\mathrm{pH}$ reconstitutions (MAAT-RMSE $=5.1^{\circ} \mathrm{C} ; \mathrm{pH}-\mathrm{RMSE}=0.56$; Huguet et al., 2019). One can anticipate that the distribution of 3-OH FAs in soils is impacted by environmental parameters other than the temperature and $\mathrm{pH}$, as observed for brGDGTs. A full 
134 understanding of the environmental parameters (e.g. MAAT, pH, soil moisture, organic carbon 135 and nitrogen content, soil types and vegetation communities) influencing bacterial lipid 136 distribution (3-OH FAs and brGDGTs) in soils is required to increase the reliability of the 137 temperature and $\mathrm{pH}$ proxies. Nevertheless, to date, there is no report of a detailed investigation 138 of the environmental controls on 3-OH FA distribution in soils and only a limited number of 139 studies on brGDGTs address this question. The aim of this work is thus to determine and 140 quantify the cumulative effect of environmental parameters on the distribution of both 141 brGDGTs and 3-OH FAs along a composite altitudinal transect in a well-constrained sampling 142 site in the French Alps. 
144

145

146

147

148

149

150

151

152

153

154

155

156

157

158

159

160

161

162

163

164

165

166

167

168

169

170

171

172

173

174

175

\subsection{Sites and sampling}

Surficial soil samples $(0-10 \mathrm{~cm}$ depth) were collected in the French Alps in October 2017 along two well-documented (MAAT, soil types and vegetation composition) climatetoposequences: the Bauges massif between 232 and 1,475 $\mathrm{m}$ a.s.l (above sea level) and the Lautaret-Galibier massif between 1,540 and 2,700 m a.s.1. (Fig. 1; Supp. Fig. 1). MAAT and a precise description of soil types and vegetation composition are available in this area thanks to an integrated long-term observatory belonging to the Zone Atelier Alpes (Bounemoura al., 1998; Carlson et al., 2017; Choler, 2018). The Lautaret-Galibier and Bauges massifs cover a complementary range of altitude and make it possible to obtain a composite altitudinal transect that is representative of the variations in temperature, soil characteristics and plant communities in the French Alps (Table 1).

\subsubsection{Bauges massif}

Twenty-four soil samples were collected along the western slope of the Bauges massif (Fig. 2; Table 1). This massif, located in the north-western part of the French Alps, in the French National Park of the Bauges massif, is a low to medium altitude site (maximum altitude of 2,217 $m$ a.s.l). To the north east, this massif is bordered by a group of mountains and the Annecy Lake. It is limited to the south west by the Bourget Lake. This is a carbonated subalpine massif, dominated by limestone chains oriented north-north-east / south-south-west. Their summits are mainly composed of Urgonian limestones. In the lower part of the massif, at an altitude of 200 $\mathrm{m}$, the Mean Annual Precipitation (MAP, mm/years) is $1,221 \mathrm{~mm}$ and the MAAT $11.4^{\circ} \mathrm{C}$ (for the period 1981-2010, Chambery meteorological station). In the upper part of the Bauges massif, at an altitude of around 1,300 $\mathrm{m}$, the annual average rainfall is $1,704.9 \mathrm{~mm}$ and the MAAT $5.8^{\circ} \mathrm{C}$ (for the period 1981-2000, Feclaz weather station; Bounemoura al., 1998; Carlson et al., 2017; Choler, 2018).

The vegetation in the lower part of the massif is characterized by mountain ash tree (Fraxinus excelsior; around $200 \mathrm{~m}$ a.s.1.) and beech (Fagus sylvatica; between 900 and 1,000 m a.s.l) forest as well as meadows, dominated by Carex foetida. The higher part of the massif is characterized by heathland patchworks (Vaccinium myrtillus species, between 1,200 and 1,350 m a.s.1.) and coniferous forest (Pinus sylvestris around $1350 \mathrm{~m}$; Fig. 2).

Soils in the lower part of the Bauges massif (around $200 \mathrm{~m}$ ) are calcosols, influenced by the limestone bedrock. Within the beech forest, organosols are present on calcareous 
substrates. Within the coniferous forest, soils are divided into patchworks of organosols resulting from the accumulation of organic litter on calcareous substrates - and brunisols, mainly resulting from the accumulation of clays in topographic hollows (Table 1).

\subsubsection{Lautaret-Galibier massif}

Twenty-five soil samples were also collected in the Roche Noire high-elevation watershed, between $1,540 \mathrm{~m}$ and 2,700 m a.s.l (Fig. 2). The site is located in the LautaretGalibier Massif, which is part of the south-western Alps, between the passes of Lautaret $(2,058$ $\mathrm{m}$ a.s.1.) and Galibier (2,645 $\mathrm{m}$ a.s.l.). Average MAP along the Lautaret-Galibier massif is 1,300 $\mathrm{mm}$ and decreases with altitude. In the lower part of the massif, at an altitude of 1,500 m, MAAT is around $6^{\circ} \mathrm{C}$. In the upper part of the massif, at an altitude of $2,700 \mathrm{~m}$, MAAT is around $0^{\circ} \mathrm{C}$. Wooded vegetation, dominated by Larch forest (Larix decidua), occurs between 1,600 m and $1,900 \mathrm{~m}$ a.s.l. Heathlands dominated by Vaccinium spp. and grasslands dominated by the tall festuce Patzkea paniculata are observed between 1,900 $\mathrm{m}$ and 2,300 $\mathrm{m}$ a.s.l. The highest part of the site is dominated by a mosaic alpine meadow showing a high beta-diversity in plant vascular species in relation with mesotopographical variations (Choler, 2018)

Calcosols are found in the lowest part of the massif, between 1,500 and 2,000 $\mathrm{m}$ a.s.1., whereas subalpine grasslands and alpine meadows are dominated by brunisols. Alocrisols developing on acidic rocks and intermediate between brunisols and podzolic soils - are also observed between 2,200 and 2,300 m a.s.l., as well as rendisols - poorly evolved and undifferentiated soils growing on calcareous substrates - at ca. 2,700 m a.s.1. and colluviosols formed by slope deposits on pre-existing soils - at ca 2,500 m a.s.l (Table 1).

\subsubsection{Sampling}

Vegetation along the two massifs (Bauges and Lautaret-Galibier) is distributed in different biomes based on the thermal regime, but also precipitation and mesotopographical parameters. Therefore, three samples representative of the different soil types and/or vegetation were collected at each elevation. A total of 49 soil samples were collected (Table 1). After being transported to the laboratory, they were directly stored at $-20{ }^{\circ} \mathrm{C}$ and then freeze-dried, ground and sieved at $2 \mathrm{~mm}$. 
Miniature temperature data loggers (Hobo Pendant UA, Onset Computer Corporation, Bourne, MA) were placed at $5 \mathrm{~cm}$ below the soil surface in 24 of the Bauges massif sites, allowing the daily measurement of the surface soil temperature. These temperatures are considered to be similar to MAAT and can be used as a first approximation as MAAT estimates

212 (Bartlett et al., 2006; Weijers et al., 2007). The corresponding data were compiled for the period 213 2016-2018 and were completed by MAAT measurements from the Feclaz meteorological 214 station (1,350 $\mathrm{m}$ a.s.l). As no recorded temperature data were available for the 2016-2018 period 215 along the Lautaret-Galibier massif, MAAT values from the Oisans massif, selected for its geographical and climatic proximity to the Lautaret-Galibier, were used instead, with 8 points distributed every $300 \mathrm{~m}$ between 750 and 3,550 m a.s.l. Data were provided by the SAFRANSURFEX/Crocus-MEPRA model chain (S2 M) developed by Météo France for the French Alps (Durand et al., 2009; Vionnet et al., 2012).

A linear regression was established between the available temperature data (Bauges and Oisans massifs as well as Feclaz station) and altitude (Supp. Fig. 2) to obtain a model allowing the reconstruction of MAAT at the different sampling sites (i.e. the whole composite transect along the Bauges and Lautaret-Galibier massifs). The MAAT values reported and discussed in the rest of the manuscript will be those obtained from this model $\left(\mathrm{R}^{2}=0.97\right.$; $\mathrm{RMSE}$ $\left.225=0.67^{\circ} \mathrm{C}\right)$.

\subsection{Bulk soil analyses}

Soil water content (SWC) was determined by difference between the soil mass before and after freeze-drying.

The $\mathrm{pH}$ of the freeze-dried samples was measured in ultrapure water with a 1:2.5 soil water ratio. Typically, $10 \mathrm{ml}$ of ultrapure water were added to $4 \mathrm{~g}$ of dry soil. The soil solution was stirred for 30 minutes, before decantation for 1 hour and $\mathrm{pH}$ measurement (Carter et al., 234 2007).

Soil samples were decarbonated before elemental (total organic carbon - Corg and 236 nitrogen) and isotopic $\left(\delta^{13} \mathrm{C}\right.$ and $\left.\delta^{15} \mathrm{~N}\right)$ analyses following the protocol detailed by Huguet et al. 237 (2013). Elemental and isotopic analyses were performed on the ALYSES platform (Sorbonne 238 University / IRD) at Bondy, France. About $10 \mu \mathrm{g}$ of decarbonated soil was typically weighed 
in tin capsules before analyses using an Elementar Vario EL III (Elementar Analysensysteme $\mathrm{GmbH}$, Germany)

The distribution of particle sizes into five sieved and crushed soil fractions - clays (< $2 \mu \mathrm{m}$ ); fine silts (between 2 and $20 \mu \mathrm{m}$ ); coarse silts (between 20 and $50 \mu \mathrm{m}$ ); fine sands (between 50 and $200 \mu \mathrm{m}$ ) and coarse sands (between 200 and $2000 \mu \mathrm{m}$ ) - was determined at the Arras Soil Laboratory, France. The cation exchange capacity (CEC) was measured in the Arras Soil Laboratory using the METSON method (Metson, 1957).

\section{3.brGDGT analysis}

Sample preparation for brGDGT analysis was similar to that reported by Coffinet et al. (2014). Briefly, ca. $10 \mathrm{~g}$ of soil was extracted using an accelerated solvent extractor (ASE 100, Dionex-ThermoScientific, USA) with a dichloromethane (DCM) / methanol (MeOH) mixture (9: 1) for $3 \times 5$ minutes at $100{ }^{\circ} \mathrm{C}$ and a pressure of 100 bars in $34 \mathrm{ml}$ cells. The total lipid extract was rotary evaporated and separated into two fractions of increasing polarity on a column of activated alumina: (i) $30 \mathrm{ml}$ of heptane: DCM (9: 1, v:v) ; (ii) $30 \mathrm{ml}$ of DCM: $\mathrm{MeOH}$ (1: 1, v:v). GDGTs are contained in the second fraction, which was rotary evaporated. An aliquot $(300 \mu \mathrm{L})$ was re-dissolved in heptane and centrifuged using an Eppendorf MiniSpin centrifuge (Eppendorf AG, Hamberg, Germany) at $7000 \mathrm{rpm}$ for $1 \mathrm{~min}$.

GDGTs were then analysed by high pressure liquid chromatography coupled with mass spectrometry with an atmospheric pressure chemical ionisation source (HPLC-APCI-MS) using a Shimadzu LCMS 2020. GDGT analysis was performed using two Hypersil Gold silica columns in tandem $(150 \mathrm{~mm} \times 2.1 \mathrm{~mm}, 1.9 \mu \mathrm{m}$; Thermo Finnigan, USA $)$ thermally-controlled at $40{ }^{\circ} \mathrm{C}$, as described by Huguet et al. (2019). This methodology enables the separation of 5 and 6-methyl brGDGTs. Semi-quantification of brGDGTs was performed by comparing the integrated signal of the respective compound with the signal of a $\mathrm{C}_{46}$ synthesized internal standard (Huguet et al., 2006) assuming their response factors to be identical.

The MBT' ${ }_{5 \mathrm{Me}}$ index, reflecting the average number of methyl groups in 5-methyl isomers of GDGTs and considered as related to MAAT, was calculated according to De Jonge et al. (2014; Eq. 1; Supp. Data): 
The CBT index, reflecting the average number of cyclopentyl rings in GDGTs and considered as related to $\mathrm{pH}$, was calculated as follows (Peterse et al., 2012; Eq. 2; Supp. Data):

$$
C B T=-\log \left(\frac{[I b]+[I I b+I I b \prime]}{[I a]+[I I a+I I a \prime]}\right)
$$

The Roman numerals correspond to the different GDGT structures presented in De Jonge et al. (2014). The 6-methyl brGDGTs are denoted by an accent after the Roman numerals for their corresponding 5-methyl isomers. Analytical errors associated with the calculation of $\mathrm{MBT}^{\prime}{ }_{5 \mathrm{Me}}$ and CBT indices are respectively 0.03 and 0.04 based on the analysis of 5 samples in triplicates among the 49 soil samples. (2019). $10 \mathrm{~g}$ of freeze-dried soil were subjected to acid hydrolysis (reflux with $30 \mathrm{ml}$ of 3M $\mathrm{HCl}$ in a $130^{\circ} \mathrm{C}$ silicon oil bath for 3 hours). The suspension was then centrifuged at $15{ }^{\circ} \mathrm{C}$ and $3000 \mathrm{rpm}$ for 10 minutes. The supernatant was collected in an Erlenmeyer flask. The residue was then ultrasonically extracted with a mixture of DCM:MeOH $(1: 1, \mathrm{v} / \mathrm{v} ; 2 \times ; 20 \mathrm{ml})$ and DCM $(2 \times ; 20 \mathrm{ml})$. Each extraction was followed by centrifugation and pooling of all extracts. The DCM phase was then separated from the $\mathrm{MeOH} / \mathrm{H}_{2} \mathrm{O}$ layer, which was again extracted with DCM (3 times; $20 \mathrm{ml}$ ). This DCM fraction was then rotary-evaporated, methylated in a $1 \mathrm{M} \mathrm{HCl}-\mathrm{MeOH}$ solution at $80{ }^{\circ} \mathrm{C}$ for 1 hour and separated into three fractions over an activated silica column: (i) $30 \mathrm{ml}$ of heptane/EtOAc (98: 2), (ii) $30 \mathrm{ml}$ of EtOAc and (iii) $30 \mathrm{ml} \mathrm{of} \mathrm{MeOH}$. 3-OH FAs contained in the second fraction were derivatised with a solution of $\mathrm{N}, \mathrm{O}$ bis(trimethylsilyl)trifluoroacetamide (BSTFA) - Trimethylchlorosilane (TMCS) 99:1 (Grace Davison Discovery Science, USA) before gas chromatography-mass spectrometry (GC-MS) analysis.

3-OH FAs were analysed with an Agilent Network 6980 GC-MS using a Restek RXI5 Sil MS silica column $(60 \mathrm{~m} \times 0.25 \mathrm{~mm}$, i.d. $0.50 \mu \mathrm{m}$ film thickness $)$, as previously described (Huguet et al., 2019). 3-OH FAs were quantified by integrating the appropriate peak $(\mathrm{m} / \mathrm{z}=$ 175) on the ion chromatogram and comparing the area with an internal standard (3hydroxytetradecanoic acid, 2,2,3,4,4-d5; Sigma-Aldrich, France). The internal standard (0.5 $\mathrm{mg} / \mathrm{ml}$ ) was added just before injection as a proportion of $3 \mu \mathrm{l}$ of standard to $100 \mu \mathrm{l}$ of sample, as detailed by Huguet et al. (2019). The different 3-OH FAs were identified based on their retention time, after extraction of the characteristic $\mathrm{m} / \mathrm{z} 175$ fragment $(\mathrm{m} / \mathrm{z} 178$ for the deuterated internal standard; cf. Huguet et al., 2019). 

$\mathrm{C}_{18}$ (Supp. Data):

$$
\text { RIAN }=-\log [(\mathrm{I}+\mathrm{A}) / \mathrm{N}]
$$

RAN $_{15}$ and RAN 17 indices are defined as follows (Wang et al., 2016; Eqs. 4 and 5; Supp. Data):

$$
\begin{aligned}
& \text { RAN }_{15}=\left[\text { anteiso } \mathrm{C}_{15}\right] /\left[\text { normal } \mathrm{C}_{15}\right] \\
& \operatorname{RAN}_{17}=\left[\text { anteiso } \mathrm{C}_{17}\right] /\left[\text { normal } \mathrm{C}_{17}\right]
\end{aligned}
$$

Analytical errors associated with the calculation of RIAN, RAN $_{15}$ and RAN $_{17}$ indices are respectively $0.009,0.19$ and 0.06 based on the analysis of one sample injected eleven times during the GC-MS analysis.

\subsection{Statistical analysis}

In order to investigate the correlations between the different environmental variables (soil moisture, $\mathrm{pH}, \mathrm{MAAT}$, Corg and $\mathrm{N}$ contents) and the relative abundances of membrane lipids (brGDGTs and 3-OH FAs), pairwise correlation matrices were performed in addition to single or multiple linear regressions. As the majority of variables are not normally distributed (except for $\delta^{15} \mathrm{~N}$ and clay content), Spearman correlation was used with a confidence level of 5\%. Linear regressions and correlation matrices were performed with R software, version 3.6.1 (R Core Team, 2014).

Redundancy analysis (RDA) was performed on the 49 soil samples to identify the relationships between environmental variables and 3-OH FA or brGDGT distribution. RDA is a "constrained" analysis, used to directly visualize the variation in the lipid data as a function of the environmental variables. Redundancy analysis allows not only assessing but also quantifying the influence of each explanatory variables (i.e. environmental variables) on the distribution of bacterial lipids. RDA analysis yields the influence of each variable, with regards to the statistical variance, on the pool of bacterial lipids, and allowed a quantification in percent of the influence of each parameter. The quantification of the effect of each variable can be considered in two ways. Simple (or marginal) effects are the effects of each variable considered independently of the other variables. Conditional effects summarize the effects of each variable taking into account the effect of variables with a greater influence (Braak and Smilauer, 2002) A forward selection was performed using the Canoco software (v. 5.04) to help in the selection of the best subset of the variables explaining the variation in 3-OH FA and brGDGT distributions. RDA analyses were performed on centered and standardized data using the 
338 CANOCO v. 5.04 software (Braak and Smilauer, 2002). The relationships between each 339 variable and the dimensions of the RDA were investigated using the corresponding r-values 340 and the percentages of variance.

341 


\subsection{Bulk soil properties}

344

The organic carbon content $\left(\mathrm{C}_{\mathrm{org}}\right)$ shows a wide range of variation - from $1.4 \%$ for poorly evolved soils (lithosol) to $49.10 \%$ for forest organosol (litter soil) - with an average of $9.7 \%$ and a standard deviation of $10.3 \%$ (Table 2). Only a minority of soils $(n=4)$ display high

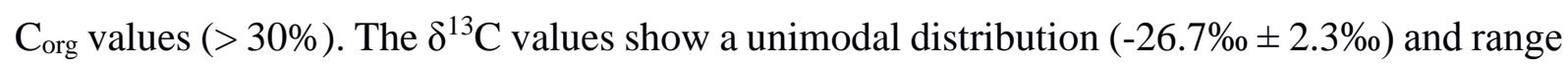
between $-29.9 \%$ and $-24.4 \%$ (Table 2). The $\mathrm{N}$ content of the soil samples is normally distributed $(0.7 \% \pm 0.5 \%$; Table 2$)$. Relative soil moisture is unimodally distributed and largely varies between soils, ranging between 3.4 and $68.2 \%$ (mean $30.3 \% \pm 15.6 \%$; Table 2). With regard to the texture of the sampled soils, the clay contents are on average $313.8 \pm 126.7 \mathrm{~g} / \mathrm{kg}$ of soil and largely vary between samples (minimum and maximum values of 33 and $546 \mathrm{~g} / \mathrm{kg}$ of soil, respectively). This large variability of the soil characteristics is also reflected in the silt $(406.4 \pm 117.0 \mathrm{~g} / \mathrm{kg}$ soil $)$ and sand $(279.8 \pm 194.1 \mathrm{~g} / \mathrm{kg}$ soil $)$ contents, as well as in the CEC values $(24.2 \pm 17.0 \mathrm{cmol}+/ \mathrm{kg}$; Table 2$)$. Finally, the $\mathrm{pH}$ values show a wide range of variation (3.62-7.49), with an average of 5.83 and a standard deviation of 1.08 .

\subsection{BrGDGT and 3-OH FA distribution}

3-OH FAs and brGDGTs were detected in the 49 studied soil samples (Supp. Tables 1 and 2). BrGDGT distribution was dominated by acyclic compounds (Ia, IIa, IIa', IIIa, IIIa') which represent in average ca. 80\% of total brGDGTs (Fig. 3a). BrGDGTs Ia and IIa were the most abundant homologues in all samples. The pentamethylated brGDGTs (IIa-c; mean 50\%, standard deviation (SD) of 6.9\%) were predominant over the tetramethylated (Ia-c) and hexamethylated (IIIa-c; Fig. 3a). The 5-methyl isomers were present in higher proportion (mean $74 \%$, SD 15.6\%) than the 6-methyl compounds (mean 26\%, SD 15\%) (Fig. 3a).

3-OH FAs with chain lengths between 8 and $26 \mathrm{C}$ were identified. These compounds may have various origins depending on their chain length (bacteria, plants and fungi; Zelles et al., 1999; Wang et al., 2016 and reference therein). Nevertheless, most of the 3-OH FAs present in our samples are homologues with 10 to $18 \mathrm{C}$ atoms, generally associated with Gram-negative bacteria (Saraf et al., 1997; Szponar et al., 2002, 2003; Keinänen et al., 2003) and only these homologues will be considered in the following. 3-OH FAs with even carbon number and normal chains were the most abundant compounds in all samples (about $65 \%$ of the 3-OH FAs, SD $12 \%$ ), with a predominance of the $n$-C $\mathrm{C}_{14}$ homologue (Fig. 3b). Iso (mean 24\%, SD 4.5\%) 
and anteiso (mean 8\%, SD 1\%) isomers were also present. It must be noted that anteiso isomers were only detected for odd 3-OH FAs (Fig. 3b).

\section{Discussion}

The distribution of brGDGTs (Weijers et al., 2007, Peterse et al., 2012; De Jonge et al., 2014) and 3-OH FAs (Wang et al., 2016; Huguet et al., 2019) in soils was reported to be influenced mainly by MAAT and soil $\mathrm{pH}$. Therefore, the effect of these two environmental parameters on the relative abundance of 3-OH FAs and brGDGTs in the 49 soils of the French Alps was first investigated.

\subsection{BrGDGTs and 3-OH FAs as proxies of $\mathrm{pH}$ and temperature}

\subsubsection{Relationship between $\mathrm{pH}$ and bacterial lipid distribution}

BrGDGT-derived CBT index has been shown to be strongly correlated with $\mathrm{pH}$ in a large set of globally distributed soils (De Jonge et al., 2014; Naafs et al., 2017). Consistently, in the French Alpine soils, CBT displayed a significant $(p<0.05)$ and strong correlation $\left(\mathrm{R}^{2}=\right.$ 0.85; RMSE $=0.42$ ) with soil $\mathrm{pH}($ Fig. $4 \mathrm{a})$, in accordance with the global CBT-pH calibration proposed by De Jonge et al, (2014). This confirms the robustness of the CBT as a soil $\mathrm{pH}$ proxy taking into account the highly contrasting environmental characteristics of these French Alps soils.

The soils of the French Alps (Table 2) and those of Mts. Rungwe, Majella and Shennongjia, previously investigated for 3-OH FA distribution (Wang et al., 2016; Huguet et al., 2019), cover a similar range of $\mathrm{pH}$ (ca. 3 -8) and of RIAN index (0.13-0.55 in the French Alps, Table 2; 0.15-0.70 for the other soils, Wang et al., 2016; Huguet et al., 2019). In the French Alps, the RIAN index was observed to be moderately $\left(\mathrm{R}^{2}=0.43\right.$; RMSE $\left.=0.83\right)$ but significantly negatively correlated $(p<0.001)$ with soil $\mathrm{pH}$ (Fig. $4 \mathrm{~b})$, consistent with the significant correlation observed along the previously investigated altitudinal transects (Wang et al., 2016; Huguet et al., 2019). This confirms the general influence of pH on the relative abundance of 3-OH FAs in soils.

Nevertheless, a stronger correlation between RIAN and $\mathrm{pH}\left(\mathrm{R}^{2}=0.62\right)$ was obtained for the dataset combining soils from Mts. Rungwe, Majella and Shennongjia (Huguet et al., 2019) compared to the one from the French Alps. In addition, the RIAN-pH correlations along the French Alps (Fig. 4b) and along Mts. Rungwe, Majella and Shennongjia (Huguet et al., 2019) displayed significantly different slopes and intercepts $(p$-value $=0.049)$, reflecting local 
trends between 3-OH FA distribution and $\mathrm{pH}$. Finally, the scatter in the RIAN-soil pH relationship along the French Alps (Fig. 4b), reflected in the average value of the prediction interval (0.35), suggests that parameters other than $\mathrm{pH}$ also affect the distribution of 3-OH FAs along this transect.

\subsubsection{Relationship between MAAT and bacterial lipid distribution}

In addition to $\mathrm{pH}$, the relationship between bacterial membrane lipid distribution and MAAT was also investigated. BrGDGT-based MBT' 5 Me was significantly $(p<0.001)$ negatively correlated with MAAT in the French Alps (Fig. 5a). Nevertheless, this correlation was substantially weaker $\left(\mathrm{R}^{2}=0.35\right)$ than the one between MAAT and MBT' or MBT' ${ }_{5 \mathrm{Me}}$ for (i) soils distributed worldwide $\left(\mathrm{R}^{2}=0.66\right.$; De Jonge et al., 2014) and (ii) along other altitudinal transects: Mount Kilimanjaro, Tanzania $\left(\mathrm{R}^{2}=0.75\right.$; Sinninghe Damsté et al., 2008); Mount Xiangpi, China $\left(\mathrm{R}^{2}=0.64\right.$; Liu et al., 2013); Mount Rungwe, Tanzania $\left(\mathrm{R}^{2}=0.74\right.$; Coffinet et al., 2014); Andean transect, Colombia $\left(R^{2}=0.67\right.$; Anderson et al., 2014), East Coast of the USA ( $\mathrm{R}^{2}=0.47$; Dirghangi et al., 2013). The lower RMSE in this study $\left(3.3{ }^{\circ} \mathrm{C}\right)$, in comparison with the RMSE of the global calibration $\left(4.8{ }^{\circ} \mathrm{C}\right)$ could be partly explained by the relatively small number of samples $(n=49)$ analyzed within the French Alps, compared to the global dataset $(n=231)$ presented by De Jonge et al. (2014). Even though the relationship between brGDGT distribution and MAAT is generally strong, there is a substantial scatter in the

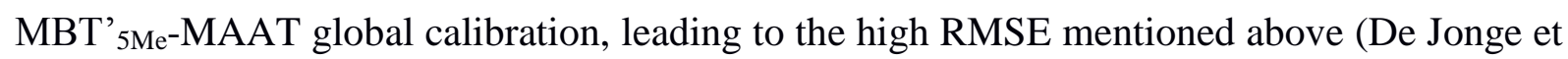
al., 2014), which reflects the heterogeneous and local response of brGDGT distribution to temperature. Such heterogeneity is also visible at the regional level, with e.g. significant differences in the relationship between brGDGT distribution and MAAT/soil $\mathrm{pH}$ along several altitudinal transects subjected to different precipitation regimes (Anderson et al., 2014). The weak relationship between $\mathrm{MBT}^{\text {' }}{ }_{5 \mathrm{Me}}$ and MAAT in the French Alps, associated with an uncertainty (RMSE) of $3.3{ }^{\circ} \mathrm{C}$, reflects the fact that local parameters other than MAAT should be the primary controls of 5-methyl brGDGT relative abundance along this specific transect.

Regarding 3-OH FAs, the temperature proxies based on these compounds, namely RAN $_{15}$ and RAN 17 , did not show any correlation with MAAT in the French Alps (Fig. 5b, c). In contrast, significant negative correlations between $\mathrm{RAN}_{15}$ and MAAT were previously observed along Mt. Shennongjia ( $\mathrm{R}^{2}=0.51$; Wang et al. 2016), Mt. Rungwe and Mt. Majella ( $\mathrm{R}^{2}$ $=0.80 ; p<0.001$ and $\mathrm{R}^{2}=0.54 ; p=0.01$, respectively; Huguet et al., 2019) with similar slopes but different intercepts. This was interpreted as the result of local effects on $\mathrm{RAN}_{15}$, despite a similar general response to temperature changes (Huguet et al., 2019). As observed for RAN $\mathrm{N}_{15}$, 
441 RAN $_{17}$ was significantly negatively correlated with MAAT along Mt. Shennongjia $\left(\mathrm{R}^{2}=0.48\right.$;

442 Wang et al. 2016), Rungwe and Majella $\left(\mathrm{R}^{2}=0.54\right.$ and 0.28 , respectively; Huguet et al., 2019)

443 with similar slopes and ordinates, showing a comparable response of $\mathrm{RAN}_{17}$ to temperature

444 variations in these different locations. Nevertheless, there was only a weak correlation between

445 RAN $_{17}$ and MAAT along Mt. Majella (Huguet et al., 2019), characterized by the closest

446 altitudinal, geographical and climatic conditions to those of the French Alps in comparison with

447 other investigated mountains. This result, combined with the absence of correlation between

448 either $\mathrm{RAN}_{15}$ or $\mathrm{RAN}_{17}$ and the MAAT in the French Alps (Fig. 5b), suggests that locally the 449 relative abundance of $\mathrm{C}_{15}$ and $\mathrm{C}_{17} 3-\mathrm{OH}$ FAs may be mainly influenced by environmental 450 parameters other than MAAT.

451 The Bauges and Lautaret-Galibier massifs, investigated in the present study, are a 452 combination of highly diverse microecosystems resulting from microtopographical and 453 geological (nature of the bedrock) differences and characterized by specific vegetation and soil 454 types, precipitation or snow cover. This multiplicity of environmental variables may therefore 455 affect the distribution of bacterial lipids in soils, as previously shown for brGDGTs (e.g. soil 456 moisture, Dirghangi et al., 2013; granulometry, Peterse and Eglinton, 2017; vegetation or soil 457 type, Davtian et al., 2016, Liang et al., 2019). This might reflect either changes in bacterial 458 communities as previously reported (Hofmann et al., 2016; Siles and Margesin, 2016; Shen et 459 al., 2019) and/or adaptation mechanisms of a constant community. Statistical analyses were 460 performed to disentangle and quantify the main drivers of changes in bacterial lipid distribution 461 along the Bauges and Lautaret-Galibier massifs and thus explain the weakness or lack of 462 correlations of the 3-OH FA-/brGDGT-derived proxies with MAAT. and brGDGT distribution using redundancy analyses (RDA), non-redundant environmental variables, which carry significantly different information, had to be selected. To this aim, a Spearman correlation matrix was first computed (Fig. 6), allowing the determination of the correlations between the different environmental variables. Highly correlated variables can be considered as redundant. Only correlation coefficients with red (negative correlation) or blue (positive correlation) colors are statistically significant $(p<0.05)$ (Fig. 6).

As MAAT values were reconstructed using a linear model with altitude (cf. section 2.1.4.), MAAT and altitude were logically anticorrelated along the Bauges and Lautaret- 
Galibier, reflecting the natural cooling of air with elevation (Fig. 6). Altitude (and thus MAAT) was moderately correlated with soil $\mathrm{pH}(\mathrm{r}=-0.44)$ and strongly correlated with $\delta^{13} \mathrm{C}(\mathrm{r}=0.77)$. A relationship between soil $\mathrm{pH}$ and altitude was similarly observed along other altitudinal gradients but the sign of the correlation was shown to be strongly site-dependent (Cheng- Jim et al., 2014; Bhandari et al., 2019). It can be influenced by multiple factors such as soil types, source rock (e.g. calcareous or granitic) or vegetation composition (e.g. presence or absence of conifers; Smith et al., 2002; Djukic et al., 2010; Gutiérrez-Girón et al., 2015). Similarly, the relationship between $\delta^{13} \mathrm{C}$ and altitude could be due to different vegetation, litter input and degradation of OM with thermal regimes, as suggested along other mountains (Wei et al., 2009; Du et al., 2014). Indeed at higher altitudes, the degradation of OM may be reduced, in contrast with the lower altitudes and higher temperatures, where plant accumulation is higher than decomposition (Davidson and Janssen, 2006; Conant et al., 2011).

Altitude is correlated to a set of environmental parameters, such as MAAT, carbon content, $\mathrm{pH}$ and can be considered as an integrative variable of the changes in vegetation, soil and relief types. In order to observe the sole effect of MAAT variation on brGDGT and 3-OH FA distribution, MAAT rather than altitude was kept as a non-redundant parameter. The $\delta^{15} \mathrm{~N}$ of the different soil samples showed moderate correlations $(r<0.7)$ with six of the eleven parameters investigated (Fig. 6) and was therefore considered as a confounding parameter. Organic carbon content $\left(\mathrm{C}_{\mathrm{org}}\right)$ of the soils was observed to be strongly correlated with the nitrogen content $(\mathrm{r}=0.97)$ and $\delta^{15} \mathrm{~N}(\mathrm{r}=-0.53)$ as well as with the cation exchange capacity ( $\mathrm{r}$ $=0.73$; Fig. 6). $\mathrm{C}_{\text {org }}$ was also moderately correlated with soil water content $(\mathrm{r}=0.64)$ and soil clay content ( $\mathrm{r}=0.54$; Fig. 6 ) and was therefore considered as a redundant variable in the present study. Similarly, based on collinearity relationships with other variables, $\mathrm{N}$ content, $\delta^{15} \mathrm{~N}$ and CEC will not be considered in the following statistical tests. In order to confirm the choice of the non-redundant variables for RDA analyses made using the Spearman correlation matrix (Fig. 6) and determine the best set of variables explaining the distribution of brGDGTs/3-OH FAs, a forward selection analysis was performed through the Canoco software. This highlighted MAAT, pH, soil moisture, sand and clay contents (reflecting the grain size gradient of the soil) as explanatory variables, in line with Spearman correlation tests (Fig. 6).

The choice of these variables for subsequent RDA analysis is not unexpected, as MAAT and $\mathrm{pH}$ were shown to have a major influence on bacterial communities, which develop adaptation mechanisms to cope with variations of such parameters (Denich et al., 2003; Beales, 2004; Fierer and Jackson, 2006). This is especially the case for brGDGT- and 3-OH FAproducing bacteria (De Jonge et al., 2019; Huguet et al., 2019). Similarly, soil moisture may 
affect the relative abundance of bacterial membrane lipids, as shown for brGDGTs (e.g. Peterse et al., 2012; Dirghangi et al., 2013; Ding et al., 2015). Soil moisture varies, as a first approximation, according to the precipitation regime, but it can also be related to other factors such as evapotranspiration, grain size or vegetation cover (Crave and Gascuel-Odoux, 1997;

513 Gómez-Plaza et al., 2001). The grain size gradient is representative of the edaphic parameters 514 which may influence bacterial diversity in soils (Hemkemeyer et al., 2018) in relationship with 515 changes in soil (micro)structure and organic matter availability and which may also in turn 516 affect the distribution of 3-OH FA and brGDGT source microorganisms in soils, as proposed 517 below.

Selecting only non-redundant variables for RDA simplifies the analysis and makes it 519 more robust. Nevertheless, RDA analyses carried out with all the variables, confirmed that MAAT, $\mathrm{pH}$ and soil moisture were the parameters mainly influencing 3-OH FA and lipid distribution (data not shown). Therefore, in the following, we will only discuss the results of the RDA analyses performed with the aforementioned non-redundant variables.

\subsubsection{RDA analysis of brGDGT distribution and environmental variables}

Regarding the RDA related to brGDGTs (Fig. 7a, Table 3), the first two axes explain $50.2 \%$ of the total inertia of the dataset. The selected environmental variables are sufficient to explain $89.4 \%$ of the variance in the brGDGT relative abundance (referred to as explained fitted variation in Table 3). On the first axis, the RDA analysis shows a predominant effect of $\mathrm{pH}(\mathrm{r}=0.96$; Table 3$)$ and a weaker contribution of MAAT $(\mathrm{r}=0.71)$ and soil moisture $(\mathrm{r}=-$

530 0.26) on the distribution of brGDGTs. Axis 2, on the other hand, is influenced by MAAT $(r=$ $5310.62)$, relative soil moisture $(\mathrm{r}=0.53)$ and to a lesser extent by $\mathrm{pH}(\mathrm{r}=-0.26)$ and soil texture parameters, with a positive correlation with the sand content $(r=0.08)$ and a negative one with the clay content $(r=-0.20$; Fig. $7 \mathrm{a}$ and Table 3$)$.

To go further, the influence of each environmental variable on the relative distribution of brGDGTs can be quantified through RDA analysis (Table 4). When the effect of each variable is considered individually, the influence of $\mathrm{pH}$ on brGDGT distribution appears predominant $(41.1 \%)$, followed by MAAT (25.2\%) and to a lesser extent soil moisture (5.3 $\%$; Table 4). This is in line with observations made from the global soil dataset by De Jonge et al. (2014), where the variance of the relative abundances of the 15 individual brGDGTs in 231 components of this PCA are considered, it appears that $\mathrm{pH}$ was positively correlated with the 
542 largest component of the variance (40\%), while MAAT and MAP were correlated together 543 with the other component $(17 \%)$.

544 In the natural environment, environmental parameters do not influence bacterial lipid distribution separately, but are interrelated and act concomitantly, with e.g. soil moisture impacting the capacity of a soil to retain heat, thus indirectly influencing the temperature (Idso et al., 1975; Davidson et al., 1998). Therefore, the combined effect of the different environmental variables on brGDGT distribution was also investigated statistically. The conditional influence of these variables (Table 4) on the brGDGT distribution shows once again a clear predominance of the effect of $\mathrm{pH}(41.1 \%)$, with a reduced influence of temperature (8.1 $\%)$, particle size $(5.5 \%)$ and soil moisture (1.5\%; Table 4). $\mathrm{pH}$, grain size (clay/sand) content and soil moisture can be all considered as variables related to the local environment, i.e. microtopography, vegetation cover and soil type. When combined together, the influence of these local parameters on brGDGT distribution amounts to $48.1 \%$ against only $8.1 \%$ for MAAT (Table 4), which can explain the weakness of the MBT' ${ }_{5 \mathrm{Me}-M A A T}$ relationship in soils from the French Alps and its large degree of scatter (Fig. 5a).

The RDA triplot also illustrates the influence of the different environmental variables on the relative abundance of the individual brGDGTs (Fig. 7a). BrGDGTs comprising cyclic moieties (i.e with subscript b or c) are strongly and mainly positively correlated with the first axis of the RDA, and thus positively correlated with $\mathrm{pH}$. As most of these cyclic compounds are used in the calculation of the CBT index, this explains the strong correlation between CBT and $\mathrm{pH}$ observed in the soils of the French Alps $\left(\mathrm{R}^{2}=0.85\right.$; Fig. 4a), consistent with the trends observed in soils distributed worldwide (De Jonge et al., 2014). In contrast with cyclic brGDGTs, acyclic 5-methyl brGDGTs (with subscript a) are located in the left half of the RDA (Fig. 7a) and show a moderate to strong correlation with the second axis of the RDA, especially brGDGT IIIa which is highly negatively influenced by MAAT. However, except compound IIIa, all the brGDGTs involved in the calculation of the MBT' ${ }_{5 \mathrm{Me}}$ are more influenced by $\mathrm{pH}$ than by temperature (Fig. 7a), hence a rather moderate correlation between this index and MAAT $\left(\mathrm{R}^{2}=0.35\right.$; Fig. 5a) is observed. Therefore, in contrast with previous studies where 5methyl brGDGT distribution in soils was suggested to be mainly affected by MAAT and to a lesser extent by soil pH (De Jonge et al., 2014, Naafs et al., 2017), the relative abundance of the 5-methyl brGDGTs in the soils from the French Alps seems to be mainly driven by soil pH, with only compound IIIa showing a strong correlation with MAAT (Fig. 7a). This may be related to a recent study by De Jonge et al. (2019), which highlighted the strong effect of $\mathrm{pH}$ on brGDGT distribution in addition to MAAT, with a different $\mathrm{pH}$-dependency in soils from warm 
and cold environments. As for the 6-methyl brGDGTs, located in the right part of the RDA (Fig. 7a), their relative abundance in the soils of the French Alps appear well-correlated with $\mathrm{pH}$, as observed in a large set of globally distributed soils $(n=350)$ by Naafs et al. (2017). BrGDGT distribution is only weakly influenced by soil moisture (especially compound Ia) and soil texture in soils from the French Alps (Fig. 7a).

\subsubsection{RDA analysis of 3-OH FA distribution and environmental variables}

584

585

Similarly to brGDGTs, RDA analysis was performed to investigate the effect of the different environmental parameters on 3-OH FA distribution (Fig. 7b). The first two axes of the RDA explain $31.8 \%$ of the total inertia of the dataset. The explained fitted variation represents $81.2 \%$ of the total inertia of the relationship between 3-OH FAs and the environmental variables (Table 3). The RDA analysis shows a predominant contribution of $\mathrm{pH}(\mathrm{r}=0.95)$, positively correlated with axis 1 , on the distribution of 3-OH FAs (Fig. 7b, Table 3). Soil moisture $(r=-0.56)$ MAAT $(r=0.29)$, sand content $(r=-0.21)$ and clay content $(r=-0.32)$ show a weaker correlation with the axis 1 . Axis 2 is mainly related to the MAAT $(r=-0.93)$, to the relative soil moisture $(\mathrm{r}=-0.41$; Fig. $7 \mathrm{~b}$, Table 3$)$ and to a lesser extent with $\mathrm{pH}(\mathrm{r}=0.23)$. Soil structure parameters (sand and clay contents) are poorly represented on the axis 2 of the RDA. (Fig. 7b; Table 3).

These qualitative trends are confirmed after quantification of the influence of each environmental variable on 3-OH FA distribution (Table 4). The study of simple effects also shows a predominant influence of $\mathrm{pH}$ on 3-OH FA distribution (20.0\%) followed by relative soil moisture $(9.9 \%)$, temperature $(11.2 \%)$ and particle size $(3.8 \%)$. The combined influence of the different variables on the 3-OH FA relative abundance shows similar results, with $\mathrm{pH}$ $(20.0 \%)$ and to a lesser extent temperature $(10.9 \%)$ and soil moisture $(3.6 \%)$ being the main parameters affecting the lipid distribution (Table 4). Like brGDGTs, the influence of local parameters related to soil type and vegetation (i.e. soil $\mathrm{pH}$, grain size content and soil moisture) on 3-OH FA distribution is predominant (26.1\%; Table 4) over MAAT, which could explain the absence of correlation between 3-OH FA distribution, especially $\mathrm{RAN}_{15}, \mathrm{RAN}_{17}$ indices and MAAT (Fig. 5b, c).

When considering the relative abundances of the individual 3-OH FAs in the RDA, it appears that most 3-OH FAs are grouped in a narrow sector of the circle (Fig. 7b). They encompass compounds with branched chains (anteiso- $\mathrm{C}_{11}$, iso- $\mathrm{C}_{12}$, iso- $\mathrm{C}_{13}$, anteiso $\mathrm{C}_{13}$, iso- $\mathrm{C}_{14}$, anteiso- $\mathrm{C}_{15}$, iso- $\mathrm{C}_{16}$, iso- $\mathrm{C}_{17}$, anteiso- $\left.\mathrm{C}_{17}\right)$, but also normal ones $\left(\mathrm{C}_{15}, \mathrm{C}_{17}\right)$. This sector is close to the positive part of the first axis and thus these compounds are mostly influenced by $\mathrm{pH}$. In 
610 contrast, this sector appears orthogonal to MAAT and opposite to soil moisture. Outside this

611 sector, the normal $\mathrm{C}_{14} 3-\mathrm{OH} F A$ is negatively correlated with the first axis and the iso $\mathrm{C}_{15}$ on 612 the one hand and the normal $\mathrm{C}_{10}$ and $\mathrm{C}_{11}$ on the other hand are respectively positively and 613 negatively correlated with the MAAT (Fig. 7b).

614 The predominant influence of $\mathrm{pH}$ on the relative abundance of all iso, anteiso and 615 normal 3-OH FAs except the iso $\mathrm{C}_{15}$, normal $\mathrm{C}_{18}$ and normal $\mathrm{C}_{10}$ homologues (Fig. 7b) explains 616 the existence of a relationship between the RIAN index and $\mathrm{pH}$ (Fig. 4b). Nevertheless, this 617 correlation remains moderate due to the rather strong and opposite influence of soil moisture 618 (Table 4) and to the (positive or negative) correlation of some 3-OH FA with MAAT. The RDA analysis also shows that the compounds used for the calculation of the $\mathrm{RAN}_{15}$ and $\mathrm{RAN}_{17}$ indices (anteiso and normal $\mathrm{C}_{15} / \mathrm{C}_{17}$ homologues) are located in the $\mathrm{pH}$ sector, orthogonal to MAAT (Fig. 7b). This explains why there are no linear relations between these indices and MAAT in soils from the French Alps (Fig. 5b, c).

623

624

625

626

627

628

629

630

631

632

633

634

635

636

637

638

639

640

641

642

643

\subsubsection{Influence of vegetation and soil type on 3-OH FA and brGDGT distribution}

As discussed above, the influence of local edaphic parameters (i.e. grain size, soil moisture, $\mathrm{pH}$ ) related to soil type and vegetation on both brGDGT and 3-OH FA distribution was shown to be higher than that of MAAT. This is further confirmed by the distribution of the samples in the RDAs (Fig. 7 a, b), with the samples being distributed according to their affiliation to certain types of soils or vegetation communities. The fact that samples are grouped in clusters may partly be due to the fact that some of them are geographically proximal. But some of the samples, spatially distant, are also clustered in the RDA, for example, according to soil types : samples 20 to 25 (calcosols, between 1,540 m and 1,940 m a.s.1), samples 5 to 7 and 17 to 19 (brunisols, between 1,920 $\mathrm{m}$ and 2,688 $\mathrm{m}$ a.s.1.), or vegetation compositions : samples 1 to 10 which are alpine meadow (between 2,531 and 2,700 m a.s.1.) (Fig. 7, Table 1). The calcosols are distributed over the entire right-hand side of the two RDAs, as they are essentially differentiated based on their alkaline $\mathrm{pH}$. The calcosols are also distributed along axis 2, driven by altitude and relative soil moisture. Thus, lowland calcosols appear in the bottom or upper right quadrants of the two RDAs respectively (Fig. 7a, b), whereas subgroups of high-altitude calcosols, reflecting mountainous and subalpine vegetation covers, can be observed at the bottom or upper right, respectively. This shows that calcosols can also be differentiated based on the plant cover patterns and altitude. In contrast with the calcosols, brunisols are distributed throughout the whole correlation circle. However, they can be subdivided into 3 distinct subgroups based on the vegetation cover and altitude: a first subgroup with intermediate altitude 
644 samples and mountainous vegetation, positively correlated with soil moisture; a second 645 subgroup, with high altitude samples and meadow vegetation, negatively correlated with 646 MAAT; a third subgroup of individuals, characterized by low altitude soils and lowland 647 vegetation, positively correlated with MAAT. Altogether, the RDA results show that soil 648 groups are discriminated according to their bacterial lipid distributions, which are strongly 649 dependent on vegetation cover and soil types.

650

651

652

653

654

655

656

657

658

659

660

\subsection{Development of local calibrations between the relative abundance of bacterial lipids and MAAT/pH}

The wide diversity of microenvironments encountered the French Alps could explain the absence or weakness of the relationships between MAAT and brGDGT-/3-OH FA-based indices, as well as between $\mathrm{pH}$ and RIAN index. This stresses the need for identifying the individual lipids whose fractional abundance is mainly correlated with MAAT or $\mathrm{pH}$, which is possible through RDA analyses (Fig. 7). The identification of these individual lipids then allow the development of local relationships between environmental parameters (MAAT/pH) and the relative abundances (\%) of the selected compounds (Figs. 8 and 9), as detailed below.

\subsubsection{BrGDGTs}

Even though the MBT' ${ }_{5 \mathrm{Me}}$ index is not suitable for MAAT reconstruction in the French Alps $\left(\mathrm{R}^{2}=0.35\right.$; Fig. 5), the RDA analysis showed that the fractional abundance of some of the brGDGTs (mainly compound III $a$ and to a lesser extent compounds $I I b$ ' and $I b$ ) are moderately to strongly correlated with MAAT. An alternate transfer function with MAAT was defined based on a linear combination of the fractional abundance of these three compounds (Eq. 6; Fig.8):

This new calibration (Eq. 6; Fig. 8) shows a much higher determination coefficient

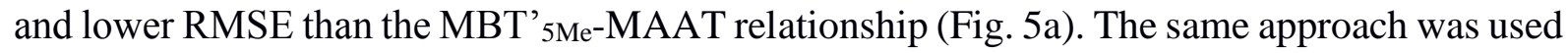
to propose a new local calibration for the brGDGTs to reconstruct $\mathrm{pH}$ values, but this did not

$$
\begin{aligned}
& \text { MAAT }=-0.255 \times[I I I a]+0.195 \times[I b]+0.171 \times\left[I I b^{\prime}\right]+6.34 \\
& \left(n=49 ; \mathrm{R}^{2}=0.69 ; \mathrm{RMSE}=2.26^{\circ} \mathrm{C}\right)
\end{aligned}
$$

$$
\text { improve the linear relationship demonstrated between the CBT index and pH (Fig. 4a). }
$$


678 Altogether, these results suggest that brGDGTs can be used for both $\mathrm{pH}$ and temperature 679 reconstructions even in highly diverse and contrasted environments such as the French Alps. 680 Nevertheless, the present study shows that a detailed investigation of the environmental controls 681 of brGDGT distribution and the development of local calibrations may be required to 682 confidently use these compounds as paleoproxies.

683

684

685

686

687

688 689

690

691

692

693

694

695

696

697

698

699

700

701

702

703

704

705 706

\subsubsection{3-OH FAs}

The RDA results allowed the identification of the individual 3-OH FAs whose relative abundance is mainly correlated with MAAT or pH (Fig. 7a). Two alternate transfer functions were proposed based on a linear combination of the relative abundance of 3-OH FAs (Eqs. 7 and 8), using a similar approach as for brGDGTs (Eq. 6 ):

$$
\begin{aligned}
& \mathrm{pH}=-0.144 \times\left[n C_{12}\right]+0.177 \times\left[i C_{13}\right]-0.171 \times\left[n C_{14}\right]+0.148 \times\left[i C_{16}\right]+10.01 \\
& \left(n=49 ; \mathrm{R}^{2}=0.70 ; \mathrm{RMSE}=0.6\right)
\end{aligned}
$$

$$
\begin{aligned}
& \text { MAAT }=-0.629 \times\left[n C_{10}\right]+0.883 \times\left[i C_{15}\right]+0.496 \times\left[i C_{17}\right]+0.629 \times\left[n C_{18}\right]-13.16 \\
& \left(n=49 ; \mathrm{R}^{2}=0.63 ; \mathrm{RMSE}=2.43^{\circ} \mathrm{C}\right)
\end{aligned}
$$

The proposed relationship between $\mathrm{pH}$ and 3-OH FA relative abundances (Eq. 7; Fig 9a) presents a higher determination coefficient $\left(R^{2}=0.70\right.$ vs. 0.43$)$ and accuracy (RMSE $=0.60$ vs. 0.83 ) than the one with the RIAN index. Similarly, the identification of the individual 3-OH FAs strongly influenced by MAAT allowed obtaining a new relationship with MAAT (Eq. 8; Fig. 9b) which was not visible through the previously defined $\mathrm{RAN}_{15}$ and $\mathrm{RAN}_{17}$ indices. This shows once again the interest and importance of constraining the environmental factors affecting the relative abundance of microbial lipids in complex and highly variable environments such as the French Alps, where conventional indices are not reliable for temperature and $\mathrm{pH}$ reconstructions. Specific calibrations have to be developed instead to take into account the effect of local confounding parameters on lipid relative distribution. 

environmental proxies

3-OH FAs were proposed only recently as potential temperature and $\mathrm{pH}$ proxies in soils and were to date investigated in a limited amount of samples - ca. 70 soils, excluding the presently studied ones (Wang et al., 2016; Huguet et al., 2019). This contrasts with brGDGTs, whose applicability as environmental proxies in terrestrial (and aquatic) environments has been extensively investigated over the last 15 years (e.g. Weijers et al., 2007; Peterse et al., 2012; Coffinet et al., 2014; De Jonge et al., 2014; Huguet et al., 2014; Dang et al., 2016; Lei et al., 2016; Naafs et al., 2017; Dearing Crampton-Flood et al., 2020). Studies investigating the constraints on the applicability of 3-OH FAs as environmental proxies in terrestrial settings are thus needed. $\mathrm{pH}$ was shown to be the main factor influencing both brGDGT and 3-OH FA distribution in soils of the French Alps, even though RIAN shows a much more moderate correlation with a lower prediction interval (Fig. $4 b ; R^{2}=0.43$, RMSE $=0.83$ ) than CBT (Fig. $4 \mathrm{a} ; \mathrm{R}^{2}=0.85, \mathrm{RMSE}=0.42$ ). The calibration between the linear combination of 3-OH FA relative abundances and $\mathrm{pH}$ proposed in this study (Eq. 7; Fig. 9a) is also slightly weaker $\left(\mathrm{R}^{2}=\right.$ $0.70)$ and less accurate $(\mathrm{RMSE}=0.60)$ than the one with the CBT (Fig. 4a). Altogether, these results show the higher reliability of the latter index as a pH proxy in the French Alps. In contrast with $\mathrm{pH}$, the MAAT was only moderately influencing the bacterial lipid distribution in soils reflected by the weak relationship between $\mathrm{MBT}^{\prime}{ }^{\mathrm{Me}}$ and MAAT and the absence of relationship of $\mathrm{RAN}_{15}$ and $\mathrm{RAN}_{17}$ with MAAT (Fig. 5). Nevertheless, the environmental variables investigated in the present study (including MAAT and $\mathrm{pH}$ ) were not able to explain the total variability of the lipid distribution, the unexplained variation remaining higher for 3 OH FAs than for brGDGTs (Table 3). Seasonality might be one of the factors influencing the production of bacterial lipids in the French Alps soils, as previously suggested for brGDGTs in the French Jura Mountains (Huguet et al., 2013). Indeed, during part of the year, some of the French Alps soils are covered with snow, protecting them from extreme temperatures. Parameters such as microtopography or snowfall are known to have an important role on the thermal regime of soils and thus on the microorganisms living in them (Margesin et al., 2008). The effect of the thermal regime could therefore explain part of the dispersion remaining in the local calibrations between MAAT and bacteria lipid distribution.

The lack of information regarding the ecology of the 3-OH FA and brGDGT producers should indeed be taken into account while discussing the high uncertainty related to the lipidbased transfer functions. $\mathrm{C}_{10}$ to $\mathrm{C}_{18} 3-\mathrm{OH}$ FAs, used for the calculation of the $\mathrm{RAN}_{15}$ and $\mathrm{RAN}_{17}$ 
$741 \mathrm{pH} /$ temperature proxies, are known to be produced by Gram-negative bacteria, which are a 742 highly diverse group of microorganisms represented by numerous genera. This non743 monophyletic group of bacteria does not share a common ancestor (Lecointre and Guyader, 744 2006), which explains the large genetic and biochemical differences between the various Gram745 negative bacteria. The numerous genera and subgenera of Gram-negative bacteria are also 746 characterized by highly diverse lipid profiles, with different relative abundances of 3-OH FAs, 747 and with the whole suite of $\mathrm{C}_{10}-\mathrm{C}_{18} 3-\mathrm{OH}$ FAs homologues not being present in all the strains 748 (Wilkinson et al., 1988). Therefore, the 3-OH FA lipid distribution is highly dependent upon 749 what Gram-negative bacterial species are present (e.g. Parker et al., 1982; Bhat and Carlson, 750 1992; Zelles, 1999). Furthermore, the diversity of Gram-negative bacteria varies with altitude 751 (Margesin et al., 2009; Siles and Margesin, 2016). Taken together, this may partly explain the 752 lack of relationship or poor to moderate correlations observed between 3-OH FA indices 753 (RAN $15 / 17$, RIAN) and MAAT/soil pH (Figs. 4b, 5b, c). Additionally, it might also not be 754 excluded that the various soil Gram-negative bacteria genera/subgenera respond differently to 755 variations of environmental parameters. In brief, the 3-OH FA profile of the various Gram756 negative bacteria species likely reflects the diversity of microenvironments present in the 757 French Alps, which are subjected concomitantly to large variations in several environmental parameters (MAAT, soil pH, soil moisture, microtopography, vegetation cover, soil type etc...). In contrast, although they appear to be ubiquitous, brGDGTs might be produced by a more restricted number of bacterial species than 3-OH FAs. Indeed, so far only soil Acidobacteria have been found to contain the building blocks of brGDGT biosynthesis and are thus considered as potential brGDGT sources (Sinninghe Damsté et al., 2018). If the diversity of brGDGT producers is indeed lower than that of 3-OH FA-producing microorganisms, it may explain the more homogenous response and lower scatter of the relationships between MAAT/pH and brGDGT-derived indices than those with 3-OH FA indices (Figs. 4 and 5). Such relationships may also be affected by the different physiological responses of brGDGT and 3OH FA producers to environmental parameters. These hypotheses remain purely speculative, as to date the information on brGDGT source microorganisms remains limited. This calls for further studies assessing and comparing the influence of environmental parameters on brGDGT and 3-OH FA producing bacteria in terrestrial environments. Such work is essential to improve the reliability and accuracy of the complementary temperature and $\mathrm{pH}$ proxies based on the two lipid families. 
This study thoroughly investigated the environmental factors controlling the distribution of brGDGTs and 3-OH FAs in soils collected along well-documented altitudinal transects in the French Alps. The influence of local parameters $(\mathrm{pH}$ and to a lesser extent soil moisture and grain size, related to vegetation and soil types) on brGDGT and 3-OH FA was more important than MAAT. This likely explains the absence or weak relationships between MAAT and brGDGT/3-OH FA-based indices and stresses the need for identifying the individual lipids whose fractional abundance is correlated with MAAT or $\mathrm{pH}$. Such work at the molecular level led to the development of strong local calibrations between the individual lipids identified through statistical analyses and MAAT/pH. They can be applied to soils from the French Alps, representative of highly contrasted microenvironments. The present study highlights the importance of constraining the environmental factors affecting the distribution of 3-OH FAs and brGDGTs in terrestrial settings prior to any environmental reconstruction using these lipid biomarkers. Such an approach should be reproduced in other sites, where local factors would also strongly influence the bacterial lipid distribution. Local effects are expected to explain a large part of the scatter observed in the global calibrations between MAAT/pH and 3-OH FA as well as brGDGT distribution. These local confounding parameters may notably explain why the calibration between 3-OH FA indices $\left(\mathrm{RAN}_{15 / 17}\right)$ and MAAT in the French Alps differ from those previously obtained in other sites. As 3-OH FAs and brGDGTs may be produced by different microorganisms, further work is needed to assess and compare the impact of environmental parameters, especially temperature and $\mathrm{pH}$, on the microbial diversity in contrasted soils and the associated lipid profiles. Even though the lack of knowledge on brGDGT-producing bacteria complicates such studies, the latter are essential to improve the reliability and accuracy of the complementary temperature and $\mathrm{pH}$ proxies based on 3-OH FAs and brGDGTs.

Acknowledgments. We thank Sorbonne Université for a $\mathrm{PhD}$ scholarship to P.V. and 803 the Labex MATISSE (Sorbonne Université) for financial support. The EC2CO program 804 (CNRS/INSU - BIOHEFECT/MICROBIEN) is thanked for funding to the SHAPE project. We thank A. Thibault for assisting in the development of new local calibrations. We are grateful to

806 P. Choler for discussions on alpine vegetation and climate, and for comments on the manuscript. 807 We thank two anonymous reviewers for their constructive comments. 
References

Anderson, V.J., Shanahan, T.M., Saylor, J.E., Horton, B.K., Mora, A.R., 2014. Sources of local and regional variability in the $\mathrm{MBT}^{\prime} / \mathrm{CBT}$ paleotemperature proxy: Insights from a modern elevation transect across the Eastern Cordillera of Colombia. Organic Geochemistry 69, 42-51.

Bartlett, M.G., Chapman, D.S., Harris, R.N., 2006. A Decade of Ground-Air Temperature Tracking at Emigrant Pass Observatory, Utah. Journal of Climate 19, 3722-3731.

Beales, N., 2004. Adaptation of Microorganisms to Cold Temperatures, Weak Acid Preservatives, Low pH, and Osmotic Stress: A Review. Comprehensive Reviews in Food Science and Food Safety 3, 1-20.

Bhandari J., Zhang Y., 2019. Effect of altitude and soil properties on biomass and plant richness in the grasslands of Tibet, China, and Manang District, Nepal. Ecosphere 10, e02915.

Bhat, U.R., Carlson, R.W., 1992. A new method for the analysis of amide-linked hydroxy fatty acids in lipid-As from gram-negative bacteria. Glycobiology 2, 535-539.

Bounemoura, Z., Lambert, K., Cadel, G., Choler, P., Manneville, O., \& Michalet, R. 1998. Influence 814 des facteurs édapho-climatiques sur la distribution des pelouses alpines dans le massif du 815 Galibier (Alpes Françaises). ECOLOGIE-BRUNOY-, 29, 53-58.

Braak, C.J.F. ter, Smilauer, P., 2002. CANOCO Reference Manual and CanoDraw for Windows User's Guide: Software for Canonical Community Ordination (version 4.5). www.canoco.com, Ithaca NY, USA.

Carlson, B.Z., Corona, M.C., Dentant, C., Bonet, R., Thuiller, W., Choler, P., 2017. Observed long-term greening of alpine vegetation - a case study in the French Alps. Environmental Research Letters 12, 114006.

Carter, M.R., Gregorich, E.G., Gregorich, E.G., 2007. Soil Sampling and Methods of Analysis. CRC Press. doi:10.1201/9781420005271

Cheng, J.Y.W., Hui, E.L.C., Lau, A.P.S., 2012. Bioactive and total endotoxins in atmospheric aerosols in the Pearl River Delta region, China. Atmospheric Environment 47, 3-11.

Cheng- Jim, J. I., Yang, Y.H., Han, W.X., He, Y.F., Smith, J., Smith, P., 2014. Climatic and edaphic controls on soil $\mathrm{pH}$ in alpine grasslands on the Tibetan Plateau, China: a quantitative analysis. Pedosphere 24, 39- 44.

Choler, P., 2018. Winter soil temperature dependence of alpine plant distribution: Implications for anticipating vegetation changes under a warming climate. Perspectives in Plant Ecology, Evolution and Systematics, Special issue on Alpine and arctic plant communities : a worldwide perspective 30,6-15.

Ciesielski, H., Sterckeman, T., Santerne, M., Willery, J., 1997. Determination of cation exchange capacity and exchangeable cations in soils by means of cobalt hexamine trichloride. Effects of experimental conditions. Agronomie 17, 1-7.

Coffinet, S., Huguet, A., Williamson, D., Fosse, C., Derenne, S., 2014. Potential of GDGTs as a temperature proxy along an altitudinal transect at Mount Rungwe (Tanzania). Organic Geochemistry 68, 82-89.

Coffinet, S., Huguet, A., Bergonzini, L., Pedentchouk, N., Williamson, D., Anquetil, C., Gałka, M., Kołaczek, P., Karpińska-Kołaczek, M., Majule, A., Laggoun-Défarge, F., Wagner, T., Derenne, S., 2018. Impact of climate change on the ecology of the Kyambangunguru crater marsh in southwestern Tanzania during the Late Holocene. Quaternary Science Reviews 196, 100-117.

Conant, R.T., Ryan, M.G., Ågren, G.I., Birge, H.E., Davidson, E.A., Eliasson, P.E., Evans, S.E., Frey, S.D., Giardina, C.P., Hopkins, F.M., Hyvönen, R., Kirschbaum, M.U.F., Lavallee, J.M., Leifeld, J., Parton, W.J., Steinweg, J.M., Wallenstein, M.D., Wetterstedt, J.Å.M., Bradford, M.A., 2011. Temperature and soil organic matter 
decomposition rates - synthesis of current knowledge and a way forward. Global

Change Biology 17, 3392-3404.

Crave, A., Gascuel- Odoux, C., 1997. The Influence of Topography on Time and Space Distribution of Soil Surface Water Content. Hydrological Processes 11, 203-210.

Dang, X., Xue, J., Yang, H., Xie, S., 2016. Environmental impacts on the distribution of microbial tetraether lipids in Chinese lakes with contrasting $\mathrm{pH}$ : Implications for lacustrine paleoenvironmental reconstructions. Science China Earth Sciences 59, 939950.

Davidson, E.A., Belk, E., Boone, R.D., 1998. Soil water content and temperature as independent or confounded factors controlling soil respiration in a temperate mixed hardwood forest. Global Change Biology 4, 217-227.

Davidson, E. A., Janssens, I.A., 2006. Temperature sensitivity of soil carbon decomposition and feedbacks to climate change. Nature 440, 165- 173.

Davtian, N., Ménot, G., Bard, E., Poulenard, J., Podwojewski, P., 2016. Consideration of soil types for the calibration of molecular proxies for soil $\mathrm{pH}$ and temperature using global soil datasets and Vietnamese soil profiles. Organic Geochemistry 101, 140-153.

De Jonge, C., Hopmans, E.C., Zell, C.I., Kim, J.-H., Schouten, S., Sinninghe Damsté, J.S., 2014. Occurrence and abundance of 6-methyl branched glycerol dialkyl glycerol tetraethers in soils: Implications for palaeoclimate reconstruction. Geochimica et Cosmochimica Acta 141, 97-112.

De Jonge, C., Radujković, D., Sigurdsson, B.D., Weedon, J.T., Janssens, I., Peterse, F., 2019. Lipid biomarker temperature proxy responds to abrupt shift in the bacterial community composition in geothermally heated soils. Organic Geochemistry 137, 103897.

Dearing Crampton-Flood, E., Tierney, J.E., Peterse, F., Kirkels, F.M.S.A., Sinninghe Damsté, J.S., 2020. BayMBT: A Bayesian calibration model for branched glycerol dialkyl glycerol tetraethers in soils and peats. Geochimica et Cosmochimica Acta 268, 142159.

Denich, T.J., Beaudette, L.A., Lee, H., Trevors, J.T., 2003. Effect of selected environmental and physico-chemical factors on bacterial cytoplasmic membranes. Journal of Microbiological Methods 52, 149-182.

Ding, S., Xu, Y., Wang, Y., He, Y., Hou, J., Chen, L., He, J.-S., 2015. Distribution of branched glycerol dialkyl glycerol tetraethers in surface soils of the Qinghai-Tibetan Plateau: implications of brGDGTs-based proxies in cold and dry regions. Biogeosciences 12, 3141-3151.

Dirghangi, S.S., Pagani, M., Hren, M.T., Tipple, B.J., 2013. Distribution of glycerol dialkyl glycerol tetraethers in soils from two environmental transects in the USA. Organic Geochemistry 59, 49-60.

Djukic, I., Zehetner, F., Tatzber, M., Gerzabek, M.H., 2010. Soil organic-matter stocks and characteristics along an Alpine elevation gradient. Journal of Plant Nutrition and Soil Science 173, 30-38.

Du, B., Liu, C., Kang, H., Zhu, P., Yin, S., Shen, G., Hou, J., Ilvesniemi, H., 2014. Climatic control on plant and soil $\delta 13 \mathrm{C}$ along an altitudinal transect of Lushan Mountain in subtropical China: Characteristics and interpretation of soil carbon dynamics. PLOS One, https://doi.org/10.1371/journal.pone.0086440.

Durand, Y., Laternser, M., Giraud, G., Etchevers, P., Lesaffre, B., \& Mérindol, L. 2009. Reanalysis of $87544 \mathrm{yr}$ of climate in the French Alps (1958-2002): methodology, model validation, climatology, 876 and trends for air temperature and precipitation. Journal of Applied Meteorology and 877 Climatology, 48(3), 429-449.

Eglinton, T.I., Eglinton, G., 2008. Molecular proxies for paleoclimatology. Earth and Planetary Science Letters $275,1-16$. 
Ernst, R., Ejsing, C.S., Antonny, B., 2016. Homeoviscous Adaptation and the Regulation of Membrane Lipids. Journal of Molecular Biology, Molecular Biology of Membrane Lipids 428, 4776-4791.

Fierer, N., Jackson, R.B., 2006. The diversity and biogeography of soil bacterial communities. Proceedings of the National Academy of Sciences 103, 626-631.

Gómez-Plaza, A., Martínez-Mena, M., Albaladejo, J., Castillo, V.M., 2001. Factors regulating spatial distribution of soil water content in small semiarid catchments. Journal of Hydrology 253, 211-226.

Gutiérrez-Girón, A., Díaz-Pinés, E., Rubio, A., Gavilán, R.G., 2015. Both altitude and vegetation affect temperature sensitivity of soil organic matter decomposition in Mediterranean high mountain soils. Geoderma 237-238, 1-8.

Hazel, J.R., Eugene Williams, E., 1990. The role of alterations in membrane lipid composition in enabling physiological adaptation of organisms to their physical environment. Progress in Lipid Research 29, 167-227.

Hemkemeyer, M., Dohrmann, A.B., Christensen, B.T., Tebbe, C.C., 2018. Bacterial Preferences for Specific Soil Particle Size Fractions Revealed by Community Analyses. Frontiers in Microbiology 9. doi:10.3389/fmicb.2018.00149

Hofmann, K., Lamprecht, A., Pauli, H., Illmer, P., 2016. Distribution of Prokaryotic Abundance and Microbial Nutrient Cycling Across a High-Alpine Altitudinal Gradient in the Austrian Central Alps is Affected by Vegetation, Temperature, and Soil Nutrients. Microbial Ecology 72, 704-716.

Hopmans, E.C., Schouten, S., Sinninghe Damsté, J.S., 2016. The effect of improved chromatography on GDGT-based palaeoproxies. Organic Geochemistry 93, 1-6.

Huguet, A., Fosse, C., Laggoun-Défarge, F., Toussaint, M.-L., Derenne, S., 2010. Occurrence and distribution of glycerol dialkyl glycerol tetraethers in a French peat bog. Organic Geochemistry 41, 559-572.

Huguet, A., Fosse, C., Laggoun-Défarge, F., Delarue, F., Derenne, S., 2013. Effects of a shortterm experimental microclimate warming on the abundance and distribution of branched GDGTs in a French peatland. Geochimica et Cosmochimica Acta 105, 294315.

Huguet, A., Francez, A.-J., Jusselme, M.D., Fosse, C., Derenne, S., 2014. A climatic chamber experiment to test the short term effect of increasing temperature on branched GDGT distribution in Sphagnum peat. Organic Geochemistry 73, 109-112.

Huguet, A., Coffinet, S., Roussel, A., Gayraud, F., Anquetil, C., Bergonzini, L., Bonanomi, G., Williamson, D., Majule, A., Derenne, S., 2019. Evaluation of 3-hydroxy fatty acids as a $\mathrm{pH}$ and temperature proxy in soils from temperate and tropical altitudinal gradients. Organic Geochemistry 129, 1-13.

Huguet, C., Hopmans, E.C., Febo-Ayala, W., Thompson, D.H., Sinninghe Damsté, J.S., Schouten, S., 2006. An improved method to determine the absolute abundance of glycerol dibiphytanyl glycerol tetraether lipids. Organic Geochemistry 37, 1036-1041.

Idso, S.B., Schmugge, T.J., Jackson, R.D., Reginato, R.J., 1975. The utility of surface temperature measurements for the remote sensing of surface soil water status. Journal of Geophysical Research (1896-1977) 80, 3044-3049.

Keinänen, M.M., Korhonen, L.K., Martikainen, P.J., Vartiainen, T., Miettinen, I.T., Lehtola, M.J., Nenonen, K., Pajunen, H., Kontro, M.H., 2003. Gas chromatographic-mass spectrometric detection of 2- and 3-hydroxy fatty acids as methyl esters from soil, sediment and biofilm. Journal of Chromatography B 783, 443-451.

Lecointre G. and Guyader H. L. 2006. The Tree of Life: A Phylogenetic Classification., Harvard 925 University Press 
Lee, A.K.Y., Chan, C.K., Fang, M., Lau, A.P.S., 2004. The 3-hydroxy fatty acids as biomarkers for quantification and characterization of endotoxins and Gram-negative bacteria in atmospheric aerosols in Hong Kong. Atmospheric Environment 38, 6307-6317.

Lei, Y., Yang, H., Dang, X., Zhao, S., Xie, S., 2016. Absence of a significant bias towards summer temperature in branched tetraether-based paleothermometer at two soil sites with contrasting temperature seasonality. Organic Geochemistry 94, 83-94.

Lepage, C., Fayolle, F., Hermann, M., Vandecasteele, J.P., 1987. Changes in Membrane Lipid Composition of Clostridium acetobutylicum during Acetone-Butanol Fermentation: Effects of Solvents, Growth Temperature and pH. Microbiology, 133, 103-110.

Liang, J., Russell, J.M., Xie, H., Lupien, R.L., Si, G., Wang, J., Hou, J., Zhang, G., 2019. Vegetation effects on temperature calibrations of branched glycerol dialkyl glycerol tetraether (brGDGTs) in soils. Organic Geochemistry 127, 1-11.

Liu, W., Wang, H., Zhang, C.L., Liu, Z., He, Y., 2013. Distribution of glycerol dialkyl glycerol tetraether lipids along an altitudinal transect on Mt. Xiangpi, NE Qinghai-Tibetan Plateau, China. Organic Geochemistry 57, 76-83.

Loomis, S.E., Russell, J.M., Ladd, B., Street-Perrott, F.A., Sinninghe Damsté, J.S., 2012. Calibration and application of the branched GDGT temperature proxy on East African lake sediments. Earth and Planetary Science Letters 357-358, 277-288.

Margesin, R., Jud, M., Tscherko, D., Schinner, F., 2009. Microbial communities and activities in alpine and subalpine soils: Communities and activities in alpine and subalpine soils. FEMS Microbiology Ecology 67, 208-218.

Menges, J., Huguet, C., Alcañiz, J.M., Fietz, S., Sachse, D., Rosell-Melé, A., 2014. Influence of water availability in the distributions of branched glycerol dialkyl glycerol tetraether in soils of the Iberian Peninsula. Biogeosciences 11, 2571-2581.

Metson, A.J., 1957. Methods of Chemical Analysis for Soil Survey Samples. Soil Science 83, 245.

Mueller-Niggemann, C., Utami, S.R., Marxen, A., Mangelsdorf, K., Bauersachs, T., Schwark, L., 2016. Distribution of tetraether lipids in agricultural soils \&ndash; differentiation between paddy and upland management. Biogeosciences 13, 1647-1666.

Naafs, B.D.A., Gallego-Sala, A.V., Inglis, G.N., Pancost, R.D., 2017. Refining the global branched glycerol dialkyl glycerol tetraether (brGDGT) soil temperature calibration. Organic Geochemistry 106, 48-56.

Naeher, S., Peterse, F., Smittenberg, R.H., Niemann, H., Zigah, P.K., Schubert, C.J., 2014. Sources of glycerol dialkyl glycerol tetraethers (GDGTs) in catchment soils, water column and sediments of Lake Rotsee (Switzerland) - Implications for the application of GDGT-based proxies for lakes. Organic Geochemistry 66, 164-173.

Peterse, F., van der Meer, J., Schouten, S., Weijers, J.W.H., Fierer, N., Jackson, R.B., Kim, J.H., Sinninghe Damsté, J.S., 2012. Revised calibration of the MBT-CBT paleotemperature proxy based on branched tetraether membrane lipids in surface soils. Geochimica et Cosmochimica Acta 96, 215-229.

Parker, J.H., Smith, G.A., Fredrickson, H.L., Vestal, J.R., White, D.C., 1982. Sensitive assay, based on 959 hydroxy fatty acids from lipopolysaccharide lipid A, from Gram negative bacteria in sediments. 960 Applied and Environmental Microbiology 44.

Peterse, F., Moy, C.M., Eglinton, T.I., 2015. A laboratory experiment on the behaviour of soilderived core and intact polar GDGTs in aquatic environments. Biogeosciences 12, 933943.

Peterse, F., Eglinton, T.I., 2017. Grain Size Associations of Branched Tetraether Lipids in Soils and Riverbank Sediments: Influence of Hydrodynamic Sorting Processes. Frontiers in Earth Science 5. doi:10.3389/feart.2017.00049 
Powers, L., Werne, J.P., Vanderwoude, A.J., Sinninghe Damsté, J.S., Hopmans, E.C., Schouten, S., 2010. Applicability and calibration of the TEX86 paleothermometer in lakes. Organic Geochemistry 41, 404-413.

R Core Team, 2014. R: A language and environment for statistical computing. R Foundation for 974 Statistical Computing, Vienna, Austria.

Russell, N.J., 1989. Adaptive modifications in membranes of halotolerant and halophilic microorganisms. Journal of Bioenergetics and Biomembranes 21, 93-113.

Russell, N.J., Evans, R.I., ter Steeg, P.F., Hellemons, J., Verheul, A., Abee, T., 1995. Membranes as a target for stress adaptation. International Journal of Food Microbiology, Physiology of Food Poisoning Microorganisms, AAIR Concerted Action PL920630 28, 255-261.

Saraf, A., Larsson, L., Burge, H., Milton, D., 1997. Quantification of ergosterol and 3-hydroxy fatty acids in settled house dust by gas chromatography-mass spectrometry: comparison with fungal culture and determination of endotoxin by a Limulus amebocyte lysate assay. Applied and Environmental Microbiology 63, 2554-2559.

Schouten, S., Hopmans, E.C., Schefuß, E., Sinninghe Damsté, J.S., 2002. Distributional variations in marine crenarchaeotal membrane lipids: a new tool for reconstructing ancient sea water temperatures? Earth and Planetary Science Letters 204, 265-274.

Schouten, S., Rijpstra, W.I.C., Durisch-Kaiser, E., Schubert, C.J., Sinninghe Damsté, J.S., 2012. Distribution of glycerol dialkyl glycerol tetraether lipids in the water column of Lake Tanganyika. Organic Geochemistry, Advances in Organic Geochemistry 2011: Proceedings of the 25th International Meeting on Organic Geochemistry 53, 34-37.

Schouten, S., Hopmans, E.C., Sinninghe Damsté, J.S., 2013. The organic geochemistry of glycerol dialkyl glycerol tetraether lipids: A review. Organic Geochemistry 54, 19-61.

Shen, C., Shi, Y., Fan, K., He, J.-S., Adams, J.M., Ge, Y., Chu, H., 2019. Soil pH dominates elevational diversity pattern for bacteria in high elevation alkaline soils on the Tibetan Plateau. FEMS Microbiology Ecology 95. doi:10.1093/femsec/fiz003

Siles, J.A., Margesin, R., 2016. Abundance and Diversity of Bacterial, Archaeal, and Fungal Communities Along an Altitudinal Gradient in Alpine Forest Soils: What Are the Driving Factors? Microbial Ecology 72, 207-220.

Sinensky, M., 1974. Homeoviscous Adaptation-A Homeostatic Process that Regulates the Viscosity of Membrane Lipids in Escherichia coli. Proceedings of the National Academy of Sciences 71, 522-525.

Singer, S.J., Nicolson, G.L., 1972. The Fluid Mosaic Model of the Structure of Cell Membranes. Science 175, 720-731.

Sinninghe Damsté, J.S., Hopmans, E.C., Pancost, R.D., Schouten, S., Geenevasen, J.A.J., 2000. Newly discovered non-isoprenoid glycerol dialkylglycerol tetraether lipids in sediments. Chemical Communications 1683-1684.

Sinninghe Damsté, J.S., Ossebaar, J., Schouten, S., Verschuren, D., 2008. Altitudinal shifts in the branched tetraether lipid distribution in soil from Mt. Kilimanjaro (Tanzania): Implications for the MBT/CBT continental palaeothermometer. Organic Geochemistry, Advances in Organic Geochemistry 2007 39, 1072-1076.

Sinninghe Damsté, J.S., Rijpstra, W.I.C., Hopmans, E.C., Weijers, J.W.H., Foesel, B.U., Overmann, J., Dedysh, S.N., 2011. 13,16-Dimethyl Octacosanedioic Acid (iso-Diabolic Acid), a Common Membrane-Spanning Lipid of Acidobacteria Subdivisions 1 and 3. Appl. Environ. Microbiol. 77, 4147-4154.

Sinninghe Damsté, J.S., W.I.C., Hopmans, E.C., Foesel, B.U., Wüst, P.K., Overmann, J., Tank, M., Bryant, D.A., Dunfield, P.F., Houghton, K., Stott, M.B., 2014. Ether- and EsterBound iso-Diabolic Acid and Other Lipids in Members of Acidobacteria Subdivision 4. Appl. Environ. Microbiol. 80, 5207-5218. 
Sinninghe Damsté, J.S.,Rijpstra, W.I.C., Foesel, B.U., Huber, K.J., Overmann, J., Nakagawa, S., Kim, J.J., Dunfield, P.F., Dedysh, S.N., Villanueva, L., 2018. An overview of the occurrence of ether- and ester-linked iso-diabolic acid membrane lipids in microbial cultures of the Acidobacteria: Implications for brGDGT paleoproxies for temperature and $\mathrm{pH}$. Organic Geochemistry 124, 63-76.

Smith, J.L., Halvorson, J.J., Bolton, H., 2002. Soil properties and microbial activity across a $500 \mathrm{~m}$ elevation gradient in a semi-arid environment. Soil Biology and Biochemistry 34, 1749-1757.

Szponar, B., Norin, E., Midtvedt, T., Larsson, L., 2002. Limitations in the use of 3-hydroxy fatty acid analysis to determine endotoxin in mammalian samples. Journal of Microbiological Methods 50, 283-289.

Szponar, B., Kraśnik, L., Hryniewiecki, T., Gamian, A., Larsson, L., 2003. Distribution of 3Hydroxy Fatty Acids in Tissues after Intraperitoneal Injection of Endotoxin. Clinical Chemistry 49, 1149-1153.

Vionnet, V., Brun, E., Morin, S., Boone, A., Faroux, S., Le Moigne, P., ... \& Willemet, J. M. (2012). 1031 The detailed snowpack scheme Crocus and its implementation in SURFEX v7. 2.

Wakeham, S.G., Pease, T.K., Benner, R., 2003. Hydroxy fatty acids in marine dissolved organic matter as indicators of bacterial membrane material. Organic Geochemistry 34, 857868.

Wang, C., Bendle, J., Yang, Y., Yang, H., Sun, H., Huang, J., Xie, S., 2016. Impacts of pH and temperature on soil bacterial 3-hydroxy fatty acids: Development of novel terrestrial proxies. Organic Geochemistry 94, 21-31.

Wang, C., Bendle, J.A., Zhang, H., Yang, Y., Liu, D., Huang, J., Cui, J., Xie, S., 2018. Holocene temperature and hydrological changes reconstructed by bacterial 3-hydroxy fatty acids in a stalagmite from central China. Quaternary Science Reviews 192, 97-105.

Wang, M., Zheng, Z., Man, M., Hu, J., Gao, Q., 2017. Branched GDGT-based paleotemperature reconstruction of the last 30,000years in humid monsoon region of Southeast China. Chemical Geology 463, 94-102.

Watanabe, Y., Takakuwa, M., 1984. Effect of Sodium Chloride on Lipid Composition of Saccharomyces rouxii. Agricultural and Biological Chemistry 48, 2415-2422.

Weber, Y., De Jonge, C., Rijpstra, W.I.C., Hopmans, E.C., Stadnitskaia, A., Schubert, C.J., Lehmann, M.F., Sinninghe Damsté, J.S., Niemann, H., 2015. Identification and carbon isotope composition of a novel branched GDGT isomer in lake sediments: Evidence for lacustrine branched GDGT production. Geochimica et Cosmochimica Acta 154, 118129.

Wei, K., Jia, G., 2009. Soil n-alkane $\delta^{13} \mathrm{C}$ along a mountain slope as an integrator of altitude effect on plant species $\delta^{13}$ C. Geophysical Research Letters 36, L11401.

Weijers, J.W.H., Schouten, S., Spaargaren, O.C., Sinninghe Damsté, J.S., 2006. Occurrence and distribution of tetraether membrane lipids in soils: Implications for the use of the TEX86 proxy and the BIT index. Organic Geochemistry, Advances in Organic Geochemistry 2005 37, 1680-1693.

Weijers, J.W.H., Schouten, S., van den Donker, J.C., Hopmans, E.C., Sinninghe Damsté, J.S., 2007. Environmental controls on bacterial tetraether membrane lipid distribution in soils. Geochimica et Cosmochimica Acta 71, 703-713.

Weijers, J.W.H., Bernhardt, B., Peterse, F., Werne, J.P., Dungait, J.A.J., Schouten, S., Sinninghe Damsté, J.S., 2011. Absence of seasonal patterns in MBT-CBT indices in mid-latitude soils. Geochimica et Cosmochimica Acta 75, 3179-3190. 
1104 Weijers, Johan W. H., Steinmann, P., Hopmans, E.C., Schouten, S., Sinninghe Damsté, J.S., 2011. Bacterial tetraether membrane lipids in peat and coal: Testing the MBT-CBT temperature proxy for climate reconstruction. Organic Geochemistry 42, 477-486. Microbial Lipids, 1063 vol. 1. Academic Press, New York, pp. 199-488.

Wollenweber, H.W., Rietschel, E.T., 1990. Analysis of lipopolysaccharide (lipid A) fatty acids. Journal of Microbiological Methods 11, 195-211.

Yang, Y., Wang, C., Bendle, J.A., Yu, X., Gao, C., Lü, X., Ruan, X., Wang, R., Xie, S., 2020. A new sea surface temperature proxy based on bacterial 3-hydroxy fatty acids. Organic Geochemistry 141, 103975.

Zell, C., Kim, J.-H., Balsinha, M., Dorhout, D., Fernandes, C., Baas, M., Sinninghe Damsté, J.S., 2014. Transport of branched tetraether lipids from the Tagus River basin to the coastal ocean of the Portuguese margin: consequences for the interpretation of the MBT'/CBT paleothermometer. Biogeosciences 11, 5637-5655.

Zelles, L., Bai, Q.Y., Rackwitz, R., Chadwick, D., Beese, F., 1995. Determination of phospholipid- and lipopolysaccharide-derived fatty acids as an estimate of microbial biomass and community structures in soils. Biology and Fertility of Soils 19, 115-123.

Zelles, L., 1999. Fatty acid patterns of phospholipids and lipopolysaccharides in the characterisation of microbial communities in soil: a review. Biology and Fertility of Soils 29, 111-129. 


\section{Figure and table captions}

Figure 1. Location of the two massifs of the French Alps investigated in this study. Images Google Satellites. Exact sampling locations is shown in Supp. Figure 1.

Figure 2. Altitudinal transect between the Bauges and Lautaret-Galibier massifs showing the dominant plant species and the different alpine stages.

Figure 3. Average distribution of (a) brGDGTs and (b) 3-OH FAs in the 49 soil samples of the French Alps.

Figure 4. (a) Linear regression between $\mathrm{CBT}$ and $\mathrm{pH}$ along the two massifs in the French Alps. The black dotted line corresponds to the global linear regression between CBT and $\mathrm{pH}$ from De Jonge et al. (2014). (b) Linear regression between RIAN and pH along the two massifs in the French Alps. The black dotted line corresponds to the linear regression between RIAN and $\mathrm{pH}$ from Huguet et al. (2019). Dotted and colored lines represent the 95\% prediction interval for each regression and colored areas represent the $95 \%$ confidence interval for each regression.

Figure 5. (a) Linear regression between MAAT and MBT' ${ }_{5 \mathrm{Me}}$ along the two massifs in the French Alps. The black dotted line corresponds to global the linear regression between MBT' ${ }_{5 \mathrm{Me}}$ and MAAT from De Jonge et al. (2014). Linear regressions between (b) RAN 15 and (c) $\mathrm{RAN}_{17}$ along the two massifs in the French Alps. Dotted and colored lines represent the 95\% prediction interval for each linear regression and colored areas represent the $95 \%$ confidence interval for each regression.

Figure 6. Correlation matrix between the different environmental variables and soil properties. Correlation coefficients in red (negative correlation) or blue (positive correlation) are statistically significant. Red variables have been chosen as explanatory variables for statistical tests.

Figure 7. Triplot presenting the results of the RDA carried out on the relative abundances of (a) brGDGTs and (b) 3-OH FAs and the non-redundant physicochemical parameters: $\mathrm{pH}$, MAAT, soil moisture, sand and clay contents.

Figure 8. MAAT estimated using the new calibration based on a linear combination of brGDGT relative abundances (Eq. 6) vs. MAAT observed along the the Bauges and LautaretGalibier massifs. The roman numerals correspond to the different GDGT structures presented in De Jonge et al. (2014).

Figure 9. (a) $\mathrm{pH}$ estimated using the new calibration based on a linear combination of 3-OH FA relative abundances (Eq. 7) vs. pH observed along the Bauges and Lautaret-Galibier massifs. (b) MAAT estimated using the new calibration based on a linear combination of 3-OH relative abundances (Eq. 8) vs. MAAT observed along the Bauges and Lautaret-Galibier massifs. The roman numerals correspond to the different GDGT structures presented in De Jonge et al. (2014).

Table 1. List of the soil samples associated with corresponding soil type and vegetation collected along the Bauges and Lautaret-Galibier massifs.

Table 2. Physicochemical characteristics of the 49 samples collected along the Bauges and Lautaret-Galibier massifs. The numbering of the samples corresponds to that used in Table 1. Samples with stars represent sites instrumented with temperature sensors. 
Table 3. RDA correlation coefficients of the environmental variables selected along axes 1 and 2.

Table 4. Quantification of the influence of the different environmental variables on brGDGTs and $3-\mathrm{OH}$ FAs. Statistical significancies are shown as follows: $* * *(0<p<0.001)$; ** $(0.001<p<0.01) ;{ }^{*}(0.01<p<0.05) ;{ }^{\circ}(0.05<p<0.1)$.

Supplementary Figure 1. Location of the sampling sites along the a) Bauges and b) LautaretGalibier massifs.

Supplementary Figure 2. Linear model used to reconstruct MAAT along the Bauges and Lautaret-Galibier massifs. Dotted lines represent the $95 \%$ prediction interval for the linear regression and colored area represent the $95 \%$ confidence interval.

Supplementary Table 1. Relative abundances (\%) of the normal, iso and anteiso 3-OH FAs in soils from the French Alps and corresponding indices.

Supplementary Table 2. Relative abundances (\%) of the brGDGTs in soils from the French Alps and corresponding indices. 

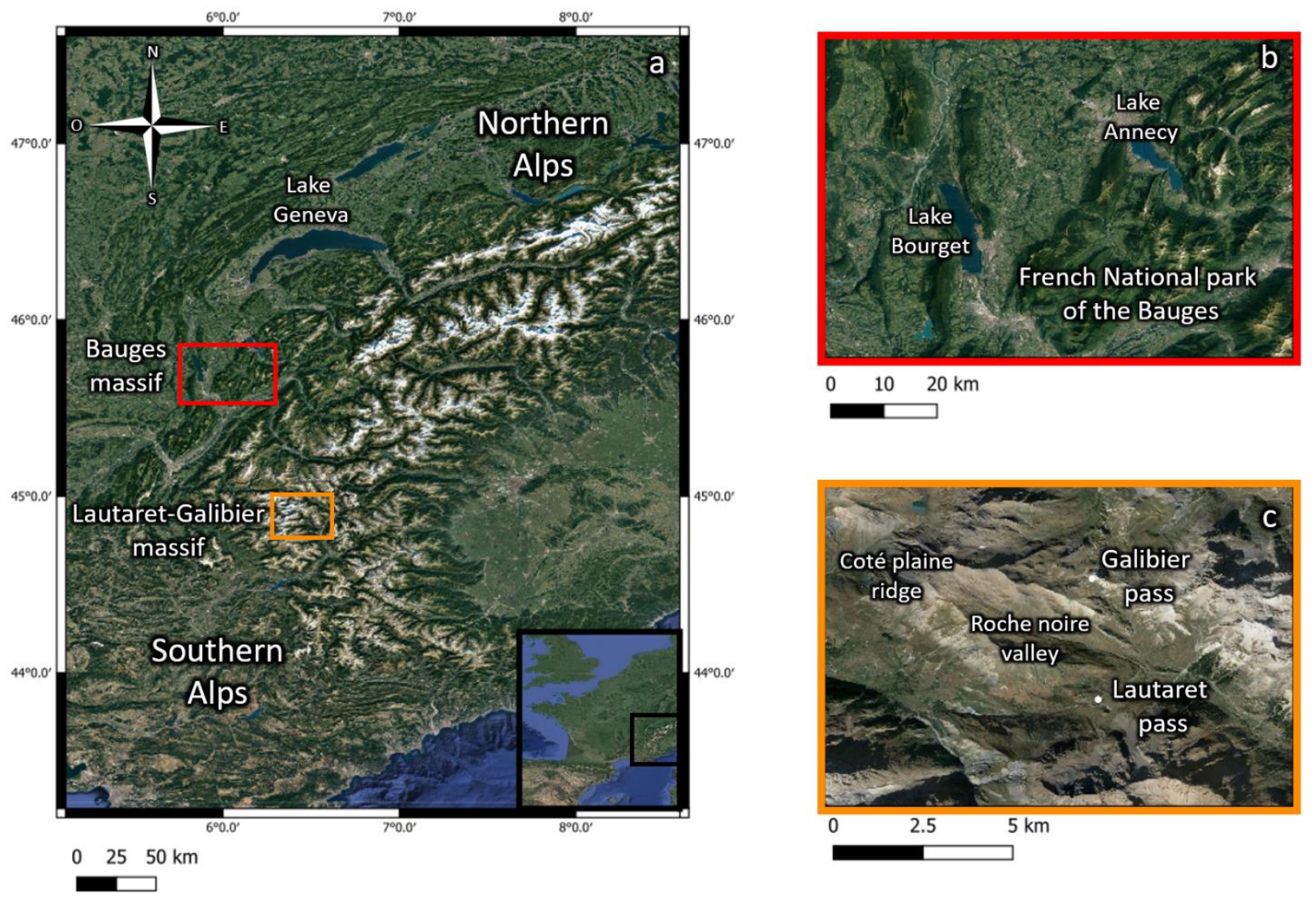

Figure 1 


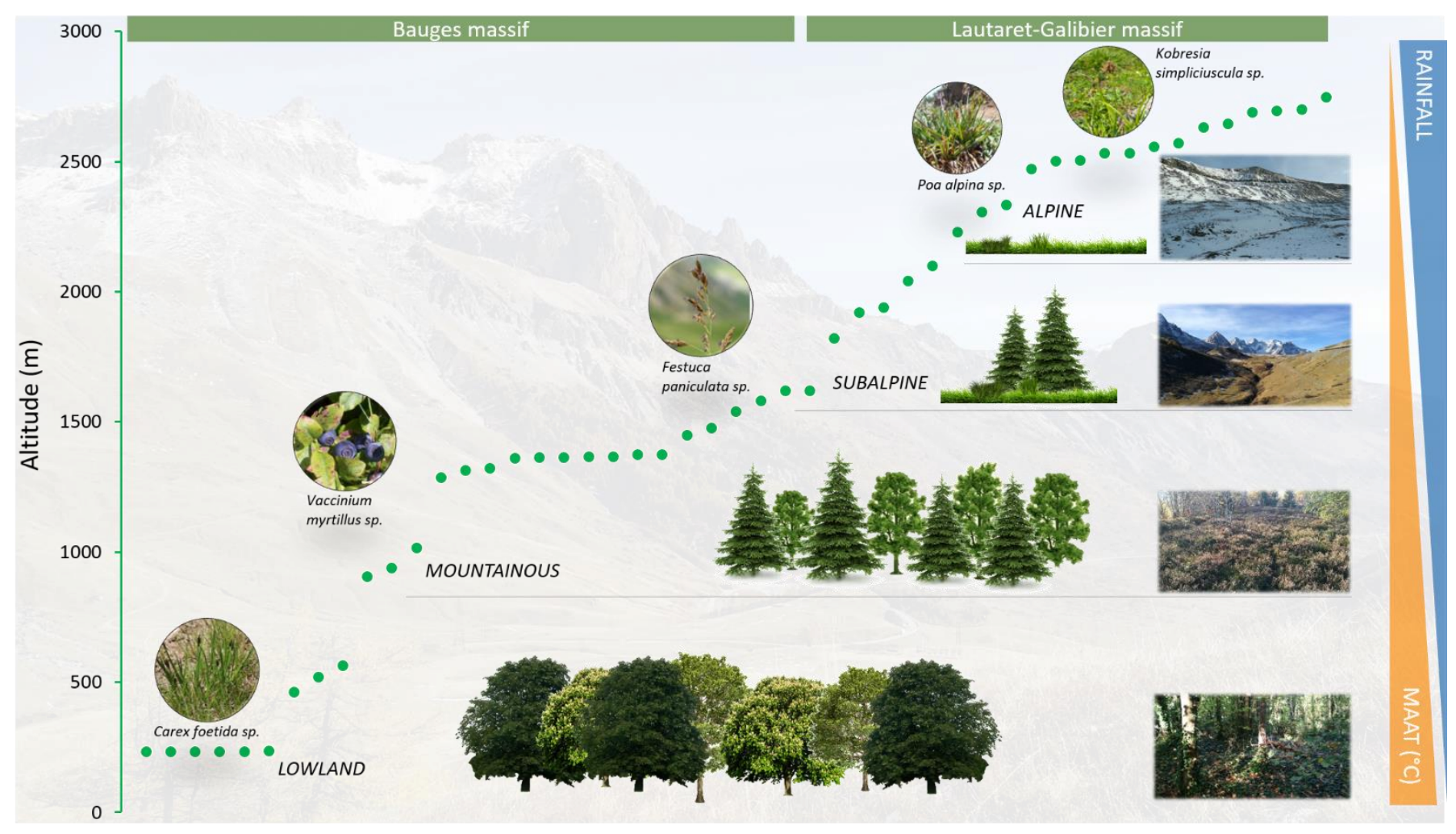

Figure 2 

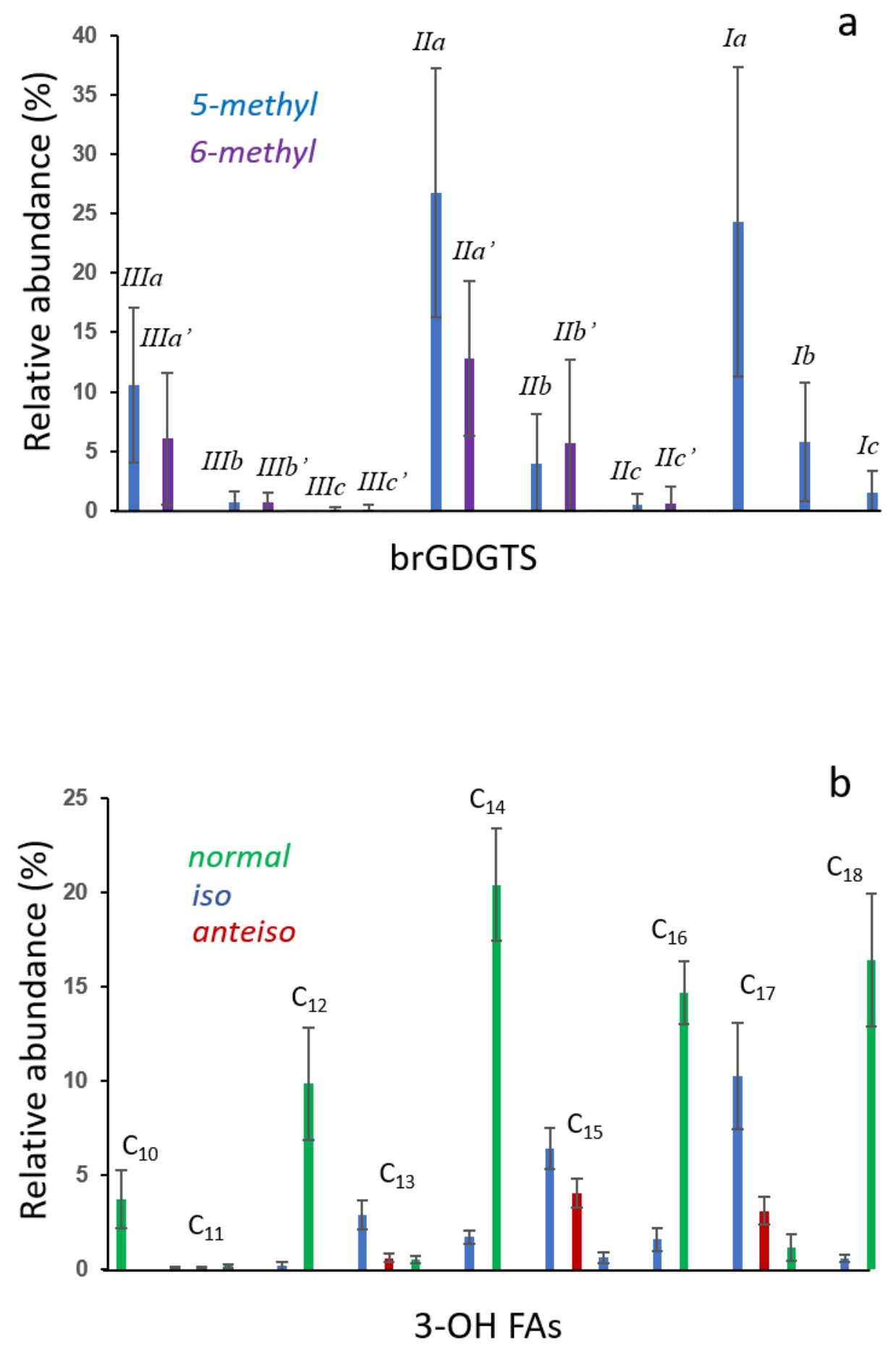

Figure 3 

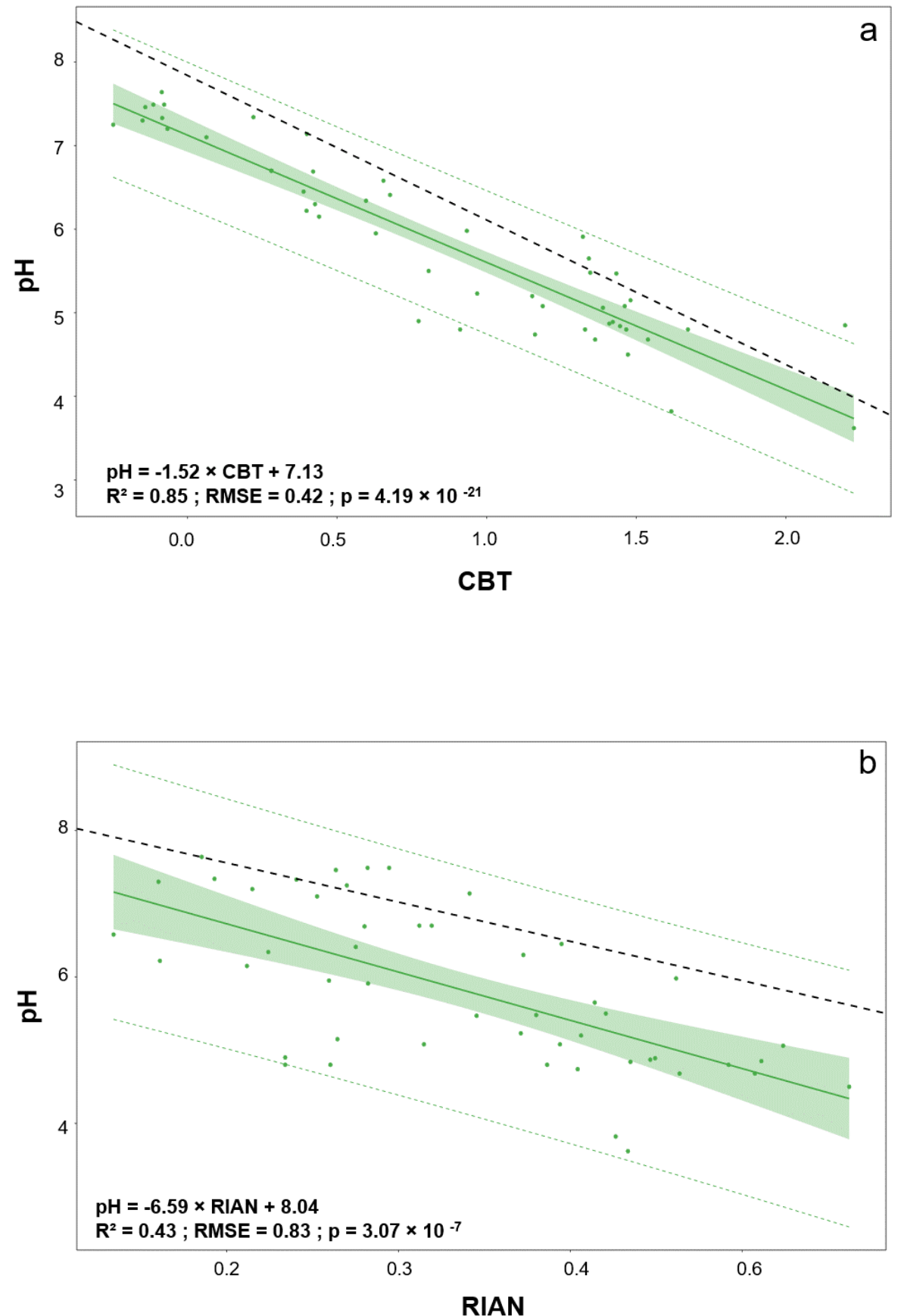

Figure 4 

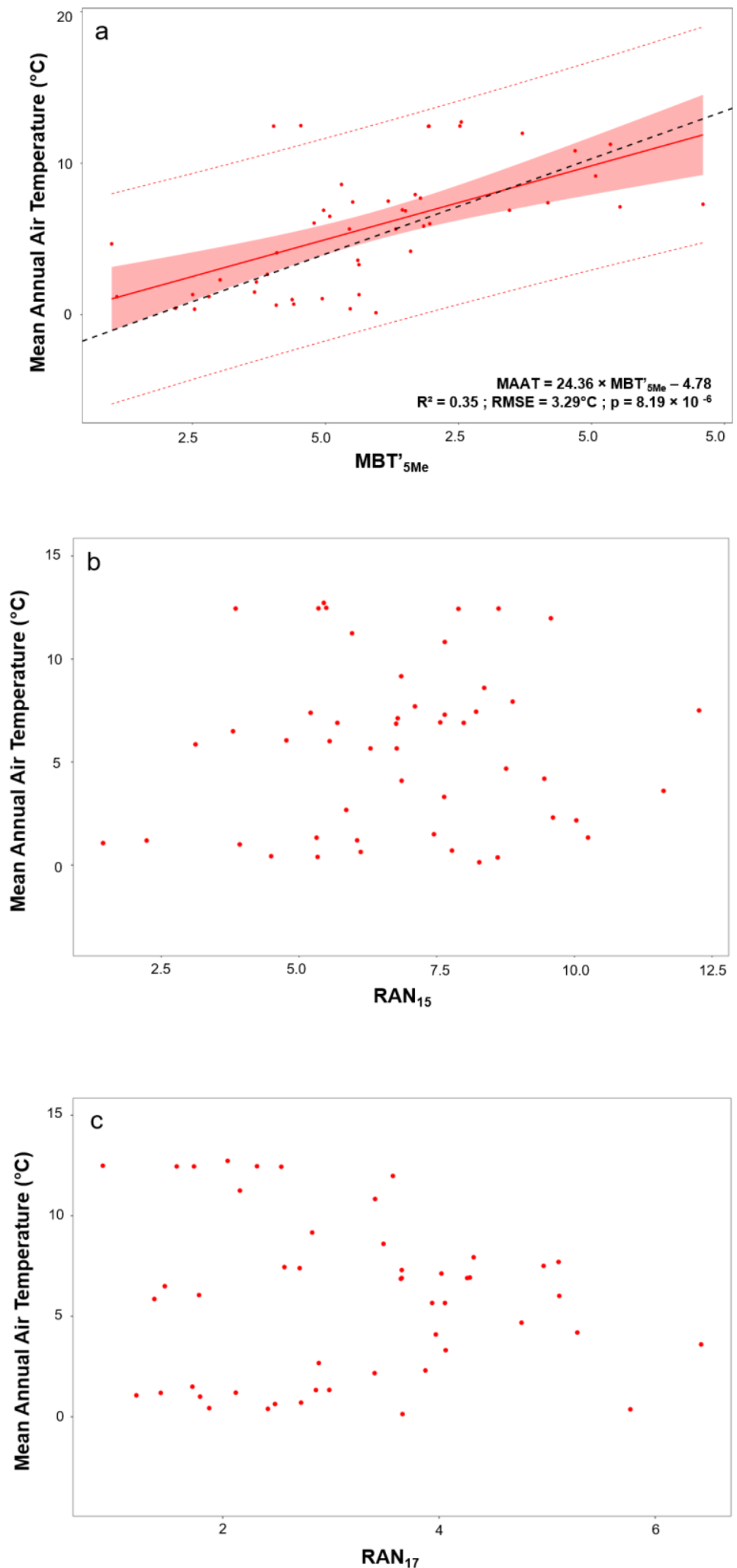

Figure 5 


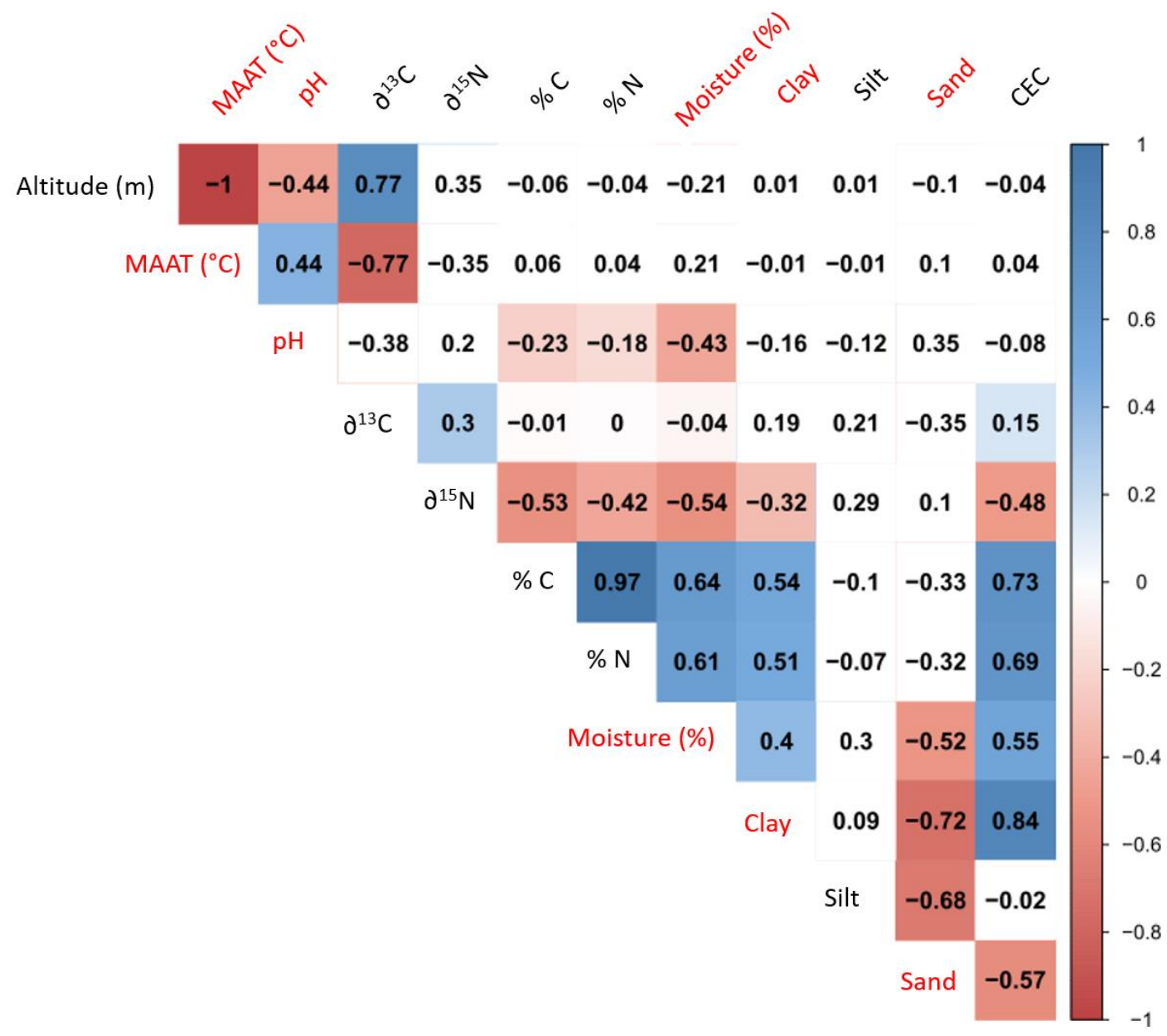

Figure 6 

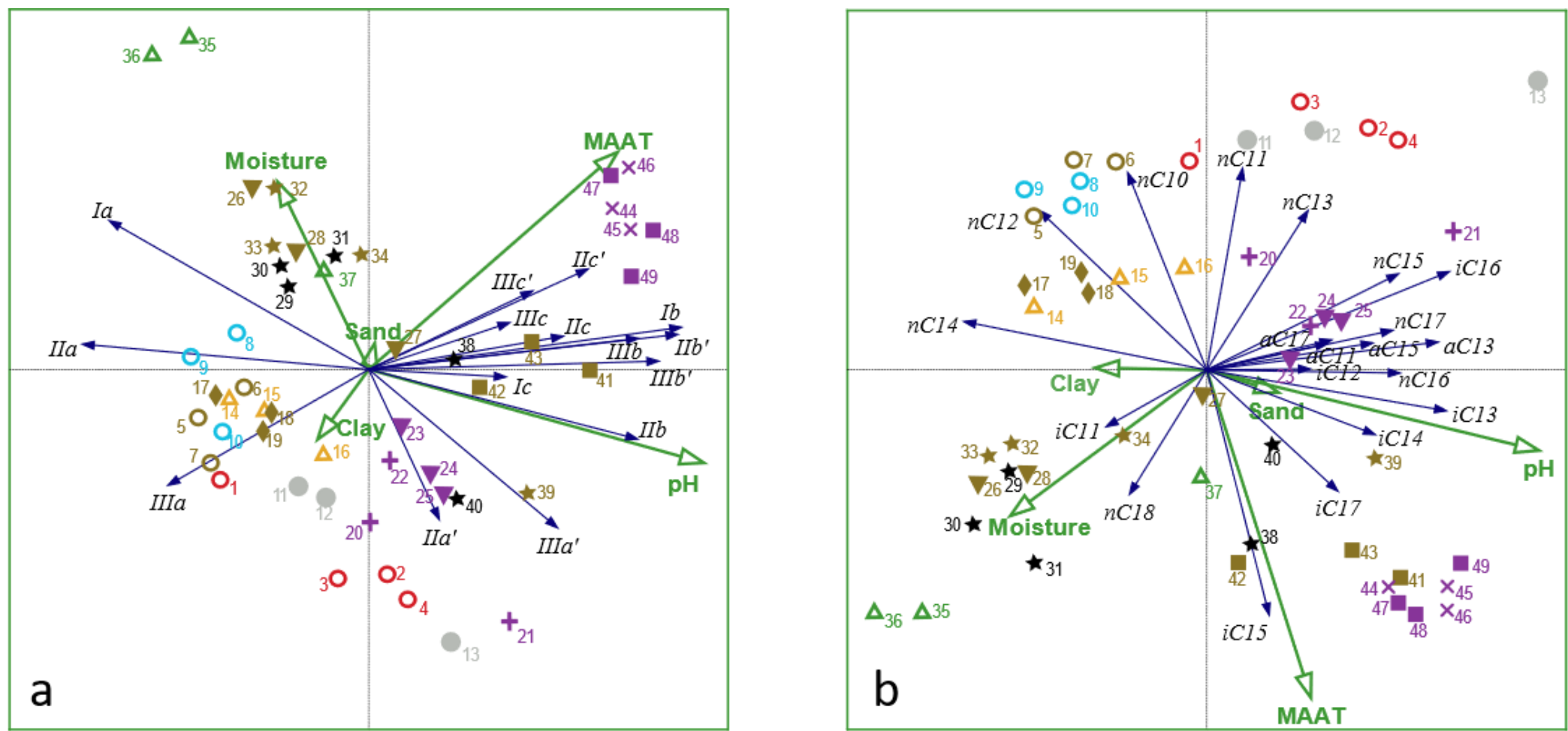

○ Alpine meadow

- Rocks

$\Delta$ Heathlands

- Subalpine meadow

+ Subalpine forest

$\boldsymbol{\nabla}$ Mountainous meadow

$\star$ Mountainous forest

- Lowland meadow

X Lowland forest $\square$ Rendisol

$\square$ Brunisol

$\square$ Colluviosol

$\square$ Lithosol

$\square$ Alocrisol

$\square$ Calcosol

Organosol

$\square$ Podzosol

Figure 7 


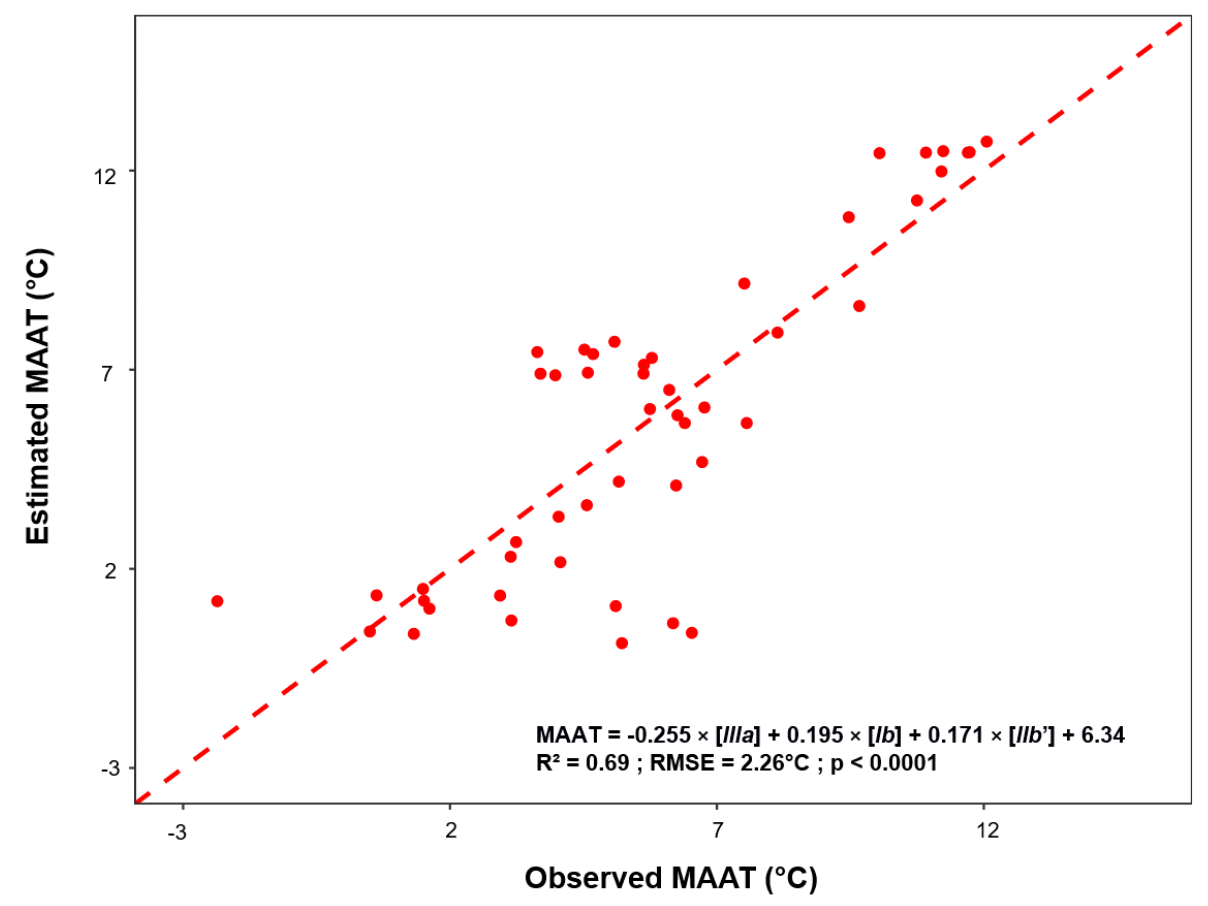

Figure 8 

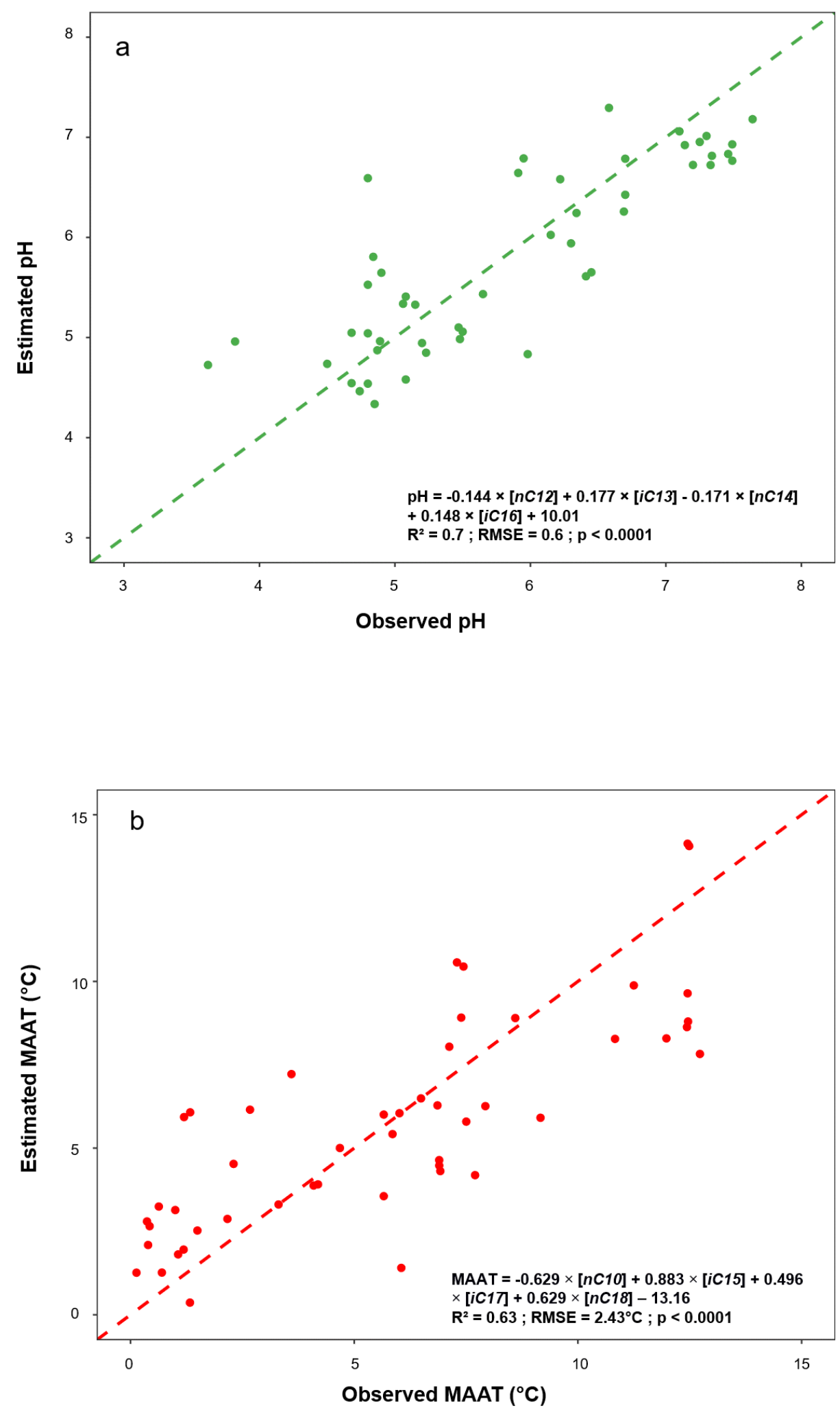

Figure 9 


\begin{tabular}{|c|c|c|c|c|c|}
\hline Samples & Massif & Coordinates & Altitude (m) & Soil Type & Vegetation \\
\hline 1 & \multirow{25}{*}{ Lautaret } & $45^{\circ} 3^{\prime} 35.24 " \mathrm{~N} 6^{\circ} 23^{\prime} 30.96 " \mathrm{E}$ & 2700 & Rendisol & Alpine meadow (Kobresia simpliciuscula) \\
\hline 2 & & $45^{\circ} 3^{\prime} 35.24 " \mathrm{~N} 6^{\circ} 23^{\prime} 30.96 " \mathrm{E}$ & 2646 & Rendisol & Alpine meadow (Kobresia simpliciuscula) \\
\hline 3 & & $45^{\circ} 3^{\prime} 36.04 " \mathrm{~N} 6^{\circ} 21^{\prime} 54.02 " \mathrm{E}$ & 2748 & Rendisol & Alpine meadow (Kobresia simpliciuscula) \\
\hline 4 & & $45^{\circ} 3^{\prime} 32.98^{\prime \prime} 6^{\circ} 22^{\prime} 4.63^{\prime \prime} \mathrm{E}$ & 2695 & Rendisol & Alpine meadow (Kobresia simpliciuscula) \\
\hline 5 & & $45^{\circ} 3^{\prime} 15.48^{\prime \prime} 6^{\circ} 24^{\prime} 3.11 " \mathrm{E}$ & 2470 & Brunisol & Alpine meadow (Poa alpina ) \\
\hline 6 & & $45^{\circ} 3^{\prime 2} 29.19^{\prime \prime N ~ 6 ² 2 ' 22.86 " E ~}$ & 2632 & Brunisol & Alpine meadow (Poa alpina ) \\
\hline 7 & & $45^{\circ} 3$ '33.77"N 6²2'9.07"E & 2688 & Brunisol & Alpine meadow (Poa alpina ) \\
\hline 8 & & $45^{\circ} 3^{\prime} 0.43 " \mathrm{~N} 6^{\circ} 23^{\prime} 6.15 " \mathrm{E}$ & 2503 & Colluviosol & Alpine meadow (Carex foetida) \\
\hline 9 & & $45^{\circ} 3^{\prime} 15.75^{\prime \prime} \mathrm{N} 6^{\circ} 22^{\prime} 30.15^{\prime \prime} \mathrm{E}$ & 2571 & Colluviosol & Alpine meadow (Carex foetida) \\
\hline 10 & & $45^{\circ} 3^{\prime} 13.32 " \mathrm{~N} 6^{\circ} 22^{\prime} 41.51 " \mathrm{E}$ & 2531 & Colluviosol & Alpine meadow (Carex foetida) \\
\hline 11 & & $45^{\circ} 2^{\prime} 55.20 " \mathrm{~N} 6^{\circ} 23^{\prime} 14.02 " \mathrm{E}$ & 2504 & Lithosol & Rocks \\
\hline 12 & & $45^{\circ} 3^{\prime} 1.99 " \mathrm{~N} 6^{\circ} 22^{\prime} 54.88 " \mathrm{E}$ & 2533 & Lithosol & Rocks \\
\hline 13 & & $45^{\circ} 3^{\prime} 10.66 " \mathrm{~N} 6^{\circ} 22^{\prime} 39.90 " \mathrm{E}$ & 2558 & Lithosol & Rocks \\
\hline 14 & & $45^{\circ} 2^{\prime} 38.94^{\prime \prime} 6^{\circ} 24^{\prime} 8.20^{\prime \prime} \mathrm{E}$ & 2230 & Alocrisol & Heathland (Vaccinium myrtillus) \\
\hline 15 & & $45^{\circ} 2^{\prime} 53.79^{\prime \prime} \mathrm{N} 6^{\circ} 23^{\prime} 45.81 " \mathrm{E}$ & 2305 & Alocrisol & Heathland (Vaccinium myrtillus) \\
\hline 16 & & $45^{\circ} 2^{\prime} 59.32 " \mathrm{~N} 6^{\circ} 23^{\prime} 32.53 " \mathrm{E}$ & 2333 & Alocrisol & Heathland (Vaccinium myrtillus) \\
\hline 17 & & $45^{\circ} 2^{\prime} 42.11 " \mathrm{~N} 6^{\circ} 24^{\prime} 25.73 " \mathrm{E}$ & 2100 & Brunisol & Subalpine meadow(Festuca paniculata) \\
\hline 18 & & $45^{\circ} 2^{\prime} 26.05^{\prime \prime N ~ 6 ² 5 ' 8.51 " E ~}$ & 1920 & Brunisol & Subalpine meadow(Festuca paniculata) \\
\hline 19 & & $45^{\circ} 2^{\prime} 25.32 " \mathrm{~N} 6{ }^{\circ} 24^{\prime} 30.39 " \mathrm{E}$ & 2041 & Brunisol & Subalpine meadow(Festuca paniculata) \\
\hline 20 & & $45^{\circ} 2 ' 22.35 " \mathrm{~N} \mathrm{6} 26^{\prime} 6.73 " \mathrm{E}$ & 1940 & Calcosol & Subalpine forest (Larix decidua) \\
\hline 21 & & $45^{\circ} 1$ '33.34"N 6²7'8.63"E & 1820 & Calcosol & Subalpine forest (Larix decidua) \\
\hline 22 & & $44^{\circ} 59^{\prime} 47.61^{\prime \prime N} 6^{\circ} 28^{\prime} 50.40 " \mathrm{E}$ & 1620 & Calcosol & Subalpine forest (Larix decidua) \\
\hline 23 & & $45^{\circ} 0^{\prime} 49.54 " \mathrm{~N} 6^{\circ} 28^{\prime} 0.44 " \mathrm{E}$ & 1620 & Calcosol & Mountainous meadow \\
\hline 24 & & $45^{\circ} 0^{\prime} 4.78^{\prime \prime} \mathrm{N} 6^{\circ} 28^{\prime} 27.34 " \mathrm{E}$ & 1580 & Calcosol & Mountainous meadow \\
\hline 25 & & $44^{\circ} 59^{\prime} 39.52^{\prime \prime} \mathrm{N} 6^{\circ} 28^{\prime} 43.30 " \mathrm{E}$ & 1540 & Calcosol & Mountainous meadow \\
\hline 26 & \multirow{24}{*}{ Bauges } & $45^{\circ} 40^{\prime} 2.47^{\prime \prime N ~ 558 ' 17.07 " E ~}$ & 1475 & Brunisol & Mountainous meadow \\
\hline 27 & & $45^{\circ} 40^{\prime} 14.96 " \mathrm{~N} 5^{\circ} 58^{\prime} 25.399^{\prime \prime} \mathrm{E}$ & 1450 & Brunisol & Mountainous meadow \\
\hline 28 & & $45^{\circ} 40^{\prime} 29.61 " \mathrm{~N} 5^{\circ} 59^{\prime} 53.47 " \mathrm{E}$ & 1360 & Brunisol & Mountainous meadow \\
\hline 29 & & $45^{\circ} 40^{\prime} 31.96 " \mathrm{~N} 5^{\circ} 59^{\prime} 46.20^{\prime \prime} \mathrm{E}$ & 1375 & Organosol & Mountainous forest \\
\hline 30 & & $45^{\circ} 40^{\prime} 33.31 " \mathrm{~N} 5^{\circ} 59^{\prime} 51.52 " \mathrm{E}$ & 1367 & Organosol & Mountainous forest \\
\hline 31 & & $45^{\circ} 40^{\prime} 27.77^{\prime \prime N} 5^{\circ} 59^{\prime} 47.87 " \mathrm{E}$ & 1362 & Organosol & Mountainous forest \\
\hline 32 & & $45^{\circ} 40^{\prime} 31.96 " \mathrm{~N} 5^{\circ} 59^{\prime} 46.20 " \mathrm{E}$ & 1375 & Brunisol & Mountainous forest \\
\hline 33 & & $45^{\circ} 40^{\prime} 33.31 " \mathrm{~N} 5^{\circ} 59^{\prime} 51.52 " \mathrm{E}$ & 1367 & Brunisol & Mountainous forest \\
\hline 34 & & $45^{\circ} 40^{\prime} 27.77^{\prime \prime} \mathrm{N} 5^{\circ} 59^{\prime} 47.87^{\prime \prime} \mathrm{E}$ & 1362 & Brunisol & Mountainous forest \\
\hline 35 & & $45^{\circ} 38^{\prime} 20.27^{\prime \prime N} 5^{\circ} 59^{\prime} 36.04 " \mathrm{E}$ & 1286 & Podzosol & Heathland (Vaccinium myrtillus) \\
\hline 36 & & $45^{\circ} 38^{\prime} 43.73^{\prime \prime N} 5^{\circ} 59^{\prime} 26.42 " \mathrm{E}$ & 1314 & Podzosol & Heathland (Vaccinium myrtillus) \\
\hline 37 & & $45^{\circ} 38^{\prime} 47.71 " \mathrm{~N} 5^{\circ} 59^{\prime} 24.09 " \mathrm{E}$ & 1321 & Podzosol & Heathland (Vaccinium myrtillus) \\
\hline 38 & & $45^{\circ} 40^{\prime} 22.12^{\prime \prime} \mathrm{N} 5^{\circ} 57^{\prime} 43.67 " \mathrm{E}$ & 905 & Organosol & Mountainous forest (Fagus sylvatica) \\
\hline 39 & & $45^{\circ} 40^{\prime} 17.69^{\prime \prime N} 5^{\circ} 57^{\prime} 44.82 " \mathrm{E}$ & 938 & Brunisol & Mountainous forest (Fagus sylvatica) \\
\hline 40 & & $45^{\circ} 40^{\prime} 6.46 " \mathrm{~N} 5^{\circ} 57^{\prime} 41.22^{\prime \prime} \mathrm{E}$ & 1017 & Organosol & Mountainous forest (Fagus sylvatica) \\
\hline 41 & & $45^{\circ} 40^{\prime} 48.07^{\prime \prime N} 5^{\circ} 56^{\prime} 30.30 " \mathrm{E}$ & 462 & Brunisol & Lowland meadow \\
\hline 42 & & $45^{\circ} 40^{\prime} 47.24 " \mathrm{~N} 5^{\circ} 57^{\prime} 1.91 " \mathrm{E}$ & 565 & Brunisol & Lowland meadow \\
\hline 43 & & $45^{\circ} 40^{\prime} 52.82^{\prime \prime N} 5^{\circ} 56^{\prime} 52.87 " \mathrm{E}$ & 520 & Brunisol & Lowland meadow \\
\hline 44 & & 453'ㄴ․․ㅇ"N 552'3.84"E & 232 & Calcosol & Lowland forest (Fraxinus excelsior) \\
\hline 45 & & $45^{\circ} 38^{\prime} 51.44 " \mathrm{~N} 5^{\circ} 52^{\prime} 3.85^{\prime \prime} \mathrm{E}$ & 234 & Calcosol & Lowland forest (Fraxinus excelsior) \\
\hline 46 & & $45^{\circ} 38^{\prime} 9.90^{\prime \prime N} 5^{\circ} 52^{\prime} 9.58 " \mathrm{E}$ & 237 & Calcosol & Lowland forest (Fraxinus excelsior) \\
\hline 47 & & $45^{\circ} 38^{\prime} 54.08 " \mathrm{~N} 5^{\circ} 51^{\prime} 58.44 " \mathrm{E}$ & 232 & Calcosol & Lowland meadow (Carex foetida) \\
\hline 48 & & $45^{\circ} 38^{\prime} 59.87 " N 5^{\circ} 52^{\prime} 0.01 " E$ & 232 & Calcosol & Lowland meadow (Carex foetida) \\
\hline 49 & & $45^{\circ} 38^{\prime} 22.21 " \mathrm{~N} 5^{\circ} 52^{\prime} 12.53 " \mathrm{E}$ & 234 & Calcosol & Lowland meadow (Carex foetida) \\
\hline
\end{tabular}

\section{Table 1}




\begin{tabular}{|c|c|c|c|c|c|c|c|c|c|c|c|}
\hline Samples & MAAT $\left({ }^{\circ} \mathbf{C}\right)$ & $\mathrm{pH}$ & C org (\%) & N (\%) & $\partial^{13} C$ & $\partial^{15} N$ & Moisture (\%) & Clay (g/kg) & Silt (g/kg) & Sand $(\mathbf{g} / \mathbf{k g})$ & $\operatorname{CEC}(\mathrm{cmol}+/ \mathrm{kg})$ \\
\hline 1 & 0.4 & 5.1 & 3.8 & 0.31 & -25.9 & 2.8 & 12.4 & 112 & 207 & 681 & 49.1 \\
\hline 2 & 0.6 & 6.3 & 6.2 & 0.59 & -25.4 & 3.0 & 27.5 & 273 & 411 & 316 & 22.6 \\
\hline 3 & 0.1 & 6.0 & 5.9 & 0.57 & -24.4 & 6.7 & 22.7 & 312 & 438 & 250 & 21.4 \\
\hline 4 & 0.4 & 6.5 & 12.7 & 1.22 & -24.9 & 2.8 & 39.4 & 323 & 407 & 270 & 38.3 \\
\hline 5 & 1.5 & 4.7 & 7.0 & 0.62 & -25.4 & 3.6 & 29.5 & 380 & 457 & 163 & 20.8 \\
\hline 6 & 0.7 & 4.9 & 5.0 & 0.46 & -25.1 & 4.3 & 30.3 & 290 & 579 & 131 & 16.1 \\
\hline 7 & 0.4 & 4.9 & 7.7 & 0.59 & -25.6 & 2.1 & 28.9 & 385 & 467 & 148 & 21 \\
\hline 8 & 1.3 & 4.8 & 2.0 & 0.21 & -25.0 & 4.0 & 26.0 & 248 & 623 & 129 & 10.3 \\
\hline 9 & 1.0 & 4.5 & 4.1 & 0.37 & -25.2 & 3.7 & 31.4 & 321 & 557 & 122 & 13.4 \\
\hline 10 & 1.2 & 4.8 & 7.3 & 0.56 & -25.7 & 8.5 & 34.1 & 378 & 461 & 161 & 19.2 \\
\hline 11 & 1.3 & 5.7 & 2.0 & 0.18 & -26.3 & 4.2 & 8.6 & 197 & 423 & 380 & 9.48 \\
\hline 12 & 1.2 & 5.9 & 1.4 & 0.15 & -25.7 & 4.2 & 9.1 & 136 & 381 & 483 & 8.27 \\
\hline 13 & 1.1 & 7.1 & 1.5 & 0.16 & -25.4 & 1.9 & 3.4 & 115 & 310 & 575 & 5.98 \\
\hline 14 & 2.7 & 4.7 & 17.8 & 1.10 & -25.8 & -0.2 & 45.8 & 448 & 406 & 146 & 31.9 \\
\hline 15 & 2.3 & 5.1 & 13.6 & 0.81 & -25.3 & 0.0 & 44.8 & 368 & 405 & 227 & 28.6 \\
\hline 16 & 2.2 & 5.5 & 17.7 & 1.22 & -25.0 & 2.0 & 52.9 & 432 & 444 & 124 & 47.5 \\
\hline 17 & 3.3 & 4.8 & 9.1 & 0.71 & -25.5 & 2.9 & 26.3 & 416 & 424 & 160 & 23.5 \\
\hline 18 & 4.2 & 5.2 & 5.9 & 0.50 & -26.1 & 2.5 & 16.6 & 377 & 420 & 203 & 20.4 \\
\hline 19 & 3.6 & 5.2 & 6.6 & 0.58 & -25.4 & 3.3 & 22.9 & 412 & 428 & 160 & 23.1 \\
\hline 20 & 4.1 & 6.2 & 6.5 & 0.57 & -25.7 & 1.7 & 16.0 & 395 & 392 & 213 & 24.6 \\
\hline 21 & 4.7 & 7.3 & 6.3 & 0.54 & -25.7 & 2.6 & 12.2 & 385 & 399 & 216 & 19.4 \\
\hline 22 & 5.7 & 6.3 & 5.1 & 0.34 & -27.4 & 1.7 & 5.8 & 194 & 232 & 574 & 13.2 \\
\hline 23 & 5.7 & 6.2 & 9.4 & 0.78 & -27.0 & 1.2 & 23.9 & 254 & 299 & 447 & 24.6 \\
\hline 24 & 5.9 & 6.6 & 7.5 & 0.64 & -26.9 & 3.2 & 11.7 & 277 & 341 & 382 & 23.3 \\
\hline 25 & 6.1 & 6.7 & 5.8 & 0.56 & -26.4 & 4.2 & 13.6 & 350 & 381 & 269 & 20.2 \\
\hline $26^{*}$ & 7.5 & 4.7 & 3.1 & 0.28 & -26.7 & 1.1 & 31.8 & 321 & 443 & 236 & 15.8 \\
\hline 27 & 6.5 & 6.0 & 3.8 & 0.40 & -26.9 & 5.1 & 33.1 & 344 & 457 & 199 & 21 \\
\hline $28^{\star}$ & 7.4 & 5.1 & 5.9 & 0.53 & -26.2 & 1.0 & 35.6 & 396 & 434 & 170 & 23.1 \\
\hline $29^{\star}$ & 6.0 & 4.9 & 32.9 & 1.89 & -26.7 & -5.0 & 61.7 & 513 & 458 & 29 & 74.7 \\
\hline 30 & 6.9 & 4.8 & 49.1 & 2.10 & -25.1 & -2.50 & 64.7 & 540 & 428 & 32 & 64.3 \\
\hline $31^{*}$ & 7.7 & 5.2 & 41.0 & 2.03 & -39.9 & -3.8 & 68.2 & 546 & 452 & 2 & 96 \\
\hline 32 & 6.9 & 4.8 & 4.7 & 0.33 & -25.6 & -1.0 & 33.7 & 305 & 525 & 170 & 21.5 \\
\hline 33 & 6.9 & 4.9 & 6.4 & 0.49 & -26.5 & 0.0 & 36.4 & 398 & 458 & 144 & 26.9 \\
\hline 34 & 6.9 & 5.5 & 6.8 & 0.42 & -25.2 & -0.8 & 39.9 & 345 & 541 & 114 & 30.5 \\
\hline 35 & 7.3 & 3.8 & 29.0 & 1.37 & -27.7 & -1.8 & 62.7 & 114 & 191 & 695 & 11.5 \\
\hline $36^{\star}$ & 7.4 & 3.6 & 31.0 & 1.74 & -28.8 & -1.5 & 53.4 & 98 & 100 & 802 & 13.2 \\
\hline 37 & 7.1 & 5.5 & 2.4 & 0.12 & -27.9 & -0.3 & 21.0 & 33 & 98 & 869 & 8.05 \\
\hline 38 & 9.2 & 6.4 & 19.8 & 1.05 & -27.9 & -2.7 & 46.4 & 411 & 285 & 304 & 32.9 \\
\hline $39^{*}$ & 8.6 & 7.2 & 11.6 & 0.88 & -26.5 & -1.0 & 28.0 & 432 & 304 & 264 & 34.7 \\
\hline $40^{\star}$ & 7.9 & 6.7 & 5.8 & 0.39 & -27.1 & -0.6 & 30.4 & 516 & 294 & 190 & 35.8 \\
\hline $41^{*}$ & 12.0 & 7.5 & 8.7 & 0.86 & -27.1 & 2.3 & 23.3 & 357 & 329 & 314 & 24.7 \\
\hline 42 & 10.8 & 6.7 & 4.3 & 0.35 & -28.4 & -0.2 & 26.1 & 477 & 314 & 209 & 28.4 \\
\hline $43^{\star}$ & 11.2 & 7.1 & 1.7 & 0.18 & -25.9 & 7.0 & 17.5 & 276 & 330 & 394 & 17.8 \\
\hline $44^{\star}$ & 12.5 & 7.3 & 5.2 & 0.53 & -27.9 & 2.9 & 26.8 & 227 & 577 & 196 & 11.8 \\
\hline 45 & 12.5 & 7.5 & 7.3 & 0.69 & -28.0 & 1.9 & 26.5 & 181 & 510 & 309 & 10.8 \\
\hline 46 & 12.4 & 7.3 & 2.7 & 0.24 & -29.4 & 1.3 & 31.6 & 95 & 501 & 404 & 9.65 \\
\hline $47^{\star}$ & 12.7 & 7.3 & 2.2 & 0.23 & -28.3 & 5.0 & 27.2 & 171 & 559 & 270 & 9.02 \\
\hline 48 & 12.5 & 7.5 & 9.8 & 0.90 & -28.7 & 2.2 & 47.2 & 327 & 599 & 74 & 26.9 \\
\hline 49 & 12.5 & 7.6 & 2.4 & 0.21 & -27.7 & 6.2 & 16.0 & 175 & 434 & 391 & 7.32 \\
\hline
\end{tabular}

Table 2 


\begin{tabular}{lcccc}
\hline \hline Variables & \multicolumn{2}{c}{ brGDGTs } & & \multicolumn{2}{c}{ 3-OH FAs } \\
\cline { 2 - 5 } & Axis 1 & Axis 2 & Axis 1 & Axis 2 \\
\cline { 2 - 5 } pH & 0.96 & -0.26 & 0.95 & 0.23 \\
MAAT ( $\left.{ }^{\circ} \mathrm{C}\right)$ & 0.71 & 0.62 & 0.29 & -0.93 \\
Moisture (\%) & -0.26 & 0.53 & -0.56 & -0.41 \\
Clay (g/kg) & -0.14 & -0.2 & -0.32 & 0.006 \\
Sand (g/kg) & 0.02 & 0.08 & -0.21 & -0.06 \\
& & & & 10.51 \\
Expl. variation (\%) & 44.09 & 6.13 & 21.27 & 26.84 \\
Expl. fitted variation (\%) & 78.47 & 10.91 & 54.39 & \\
\hline \hline
\end{tabular}

Table 3 


\begin{tabular}{c|c|c|c|c}
\hline \hline \multirow{2}{*}{ Variables } & \multicolumn{2}{|c|}{ brGDGTs } & \multicolumn{2}{c}{ 3-OH FAs } \\
\hline & Simple effets (\%) & Conditional effects (\%) & Simple effets (\%) & Conditional effects (\%) \\
\cline { 2 - 5 } pH & $41.1 * * *$ & $41.1^{* * *}$ & $20.0 * * *$ & $20.0^{* * *}$ \\
MAAT $\left({ }^{\circ} \mathrm{C}\right)$ & $25.2^{* * *}$ & $8.1^{* * *}$ & $11.2^{* *}$ & $10.9^{* * *}$ \\
Moisture (\%) & $5.3^{*}$ & $1.5^{\circ}$ & $9.9 * * *$ & $3.6^{*}$ \\
Clay (g/kg) & 2.8 & $2.0^{*}$ & $3.8^{\circ}$ & $2.5^{\circ}$ \\
Sand (g/kg) & 1.4 & $3.5^{* * *}$ & 2.1 & 2.2 \\
\hline \hline
\end{tabular}

\section{Table 4}

